\title{
The Impacts of Microcredit: Evidence from Ethiopia
}

\author{
Alessandro Tarozzi, Jaikishan Desai and Kristin Johnson
}

March $2014^{*}$

\begin{abstract}
We use data from a randomized controlled trial conducted in 2003-2006 in rural Amhara and Oromiya (Ethiopia) to study the impacts of increasing access to microfinance on a number of socio-economic outcomes, including income from agriculture, animal husbandry, non-farm selfemployment, labor supply, schooling and indicators of women's empowerment. We document that despite substantial increases in borrowing in areas assigned to treatment the null of no impact cannot be rejected for a large majority of outcomes.
\end{abstract}

Key words: Microcredit; Cluster Randomized Controlled Trial; Ethiopia

JEL codes: 012 , O16

${ }^{*}$ We are very grateful to Family Health International for granting us access to the data and to Charles Becker, Cristina Czura, Simon Quinn, Duncan Thomas, Chris Woodruff, Esther Duflo (the Editor), two anonymous referees and seminar participants at several seminars and workshops for comments and suggestions. All errors and omissions are our own. The trial described in the paper has been registered after the conclusion of the study with the AER RCT Registry, with registry number AEARCTR-0000305. Corresponding author: Alessandro Tarozzi (alessandro.tarozzi@upf.edu): Department of Economics and Business, Universitat Pompeu Fabra and Barcelona GSE, Ramon Trias Fargas, 25-27 08005 Barcelona, Spain; Kristin Johnson (kristinjohnson36@gmail.com), Senior Research Associate, Harvard Business School, Cambridge MA; Jaikishan Desai (Jaikishan.Desai@vuw.ac.nz): Health Services Research Centre, School of Government, Victoria University of Wellington, New Zealand. 


\section{Introduction}

Beginning in the 1970s, with the birth of the Grameen Bank in Bangladesh, microcredit has played a prominent role among development initiatives. Many proponents claim that micro-finance has had enormously positive effects among borrowers. However, the rigorous evaluation of such claims of success has been complicated by the endogeneity of program placement and client selection, both common obstacles in program evaluations. Micro-finance institutions (MFIs) typically choose to locate in areas predicted to be profitable, and/or where large impacts are expected. In addition, individuals who seek out loans in areas served by MFIs and that are willing and able to form jointliability borrowing groups (a model often preferred by MFIs) are likely different from others who do not along a number of observable and unobservable factors. Until recently, the results of most evaluations could not be interpreted as conclusively causal because of the lack of an appropriate control group (see Brau and Woller 2004 and Armendariz de Aghion and Morduch 2005 for comprehensive early surveys). In this context, randomized controlled trials (RCTs) provide an ideal research design to evaluate the impact of microcredit.

In this paper we present the results of one of the few existing RCTs that evaluate the impact of introducing access to microloans in poor communities in a developing country after the early contribution of Banerjee et al. (2013). We study a large-scale clustered RCT conducted in rural Amhara and Oromiya (Ethiopia) between 2003 and 2006. The main purpose of the RCT was to evaluate whether the contemporaneous introduction of microcredit and community-driven family planning programs (FPPs) could have a larger impact on contraceptive use than either program operating on its own. The study was conducted using a $2 \times 2$ factorial design where 133 local administrative units called kebeles or 'peasant associations' (PAs) were randomly assigned to one of four group: micro-lending only, FPP only, both, or none (control). Despite the primary emphasis on contraceptive use, household surveys conducted before and after the interventions also measured a broad range of socio-economic outcomes, including income-generating activities, livestock ownership, schooling and measures of women's empowerment. Because the study design assigned a randomly determined subset of community to have access to microloans, the data can be used to gauge the impact of increased access to microfinance on the economic lives of households in study areas.

Ours should be a useful addition to a small number of RCTs that evaluate how increasing access to microloans at the community level may affect socio-economic outcomes in poor countries. Other 
studies evaluate impacts in urban slums in Hyderabad (India) (Banerjee et al. 2013), in rural and urban areas of the state of Sonora, Mexico (Angelucci et al. 2014), in rural Mongolia (Attanasio et al. 2013) and rural Morocco (Crépon et al. 2011). ${ }^{1}$ Other RCTs have estimated the impact of access to microcredit by randomizing at the individual level among micro-credit clients close to the threshold of eligibility for loans, see Karlan and Zinman (2010, urban South Africa), Karlan and Zinman (2011, urban Philippines) and Augsburg et al. (2012, Bosnia-Herzegovina).

In our study, we use data collected during a pre-intervention household survey carried out in 2003 ('baseline') and a post-intervention survey completed three years later ('follow-up' or 'endline'). Each survey was conducted by interviewing about 6,000 households, with similar sample size from the two regions of Amhara and Oromiya. At follow-up, interviewers re-visited the same study villages, but they did not seek to re-interview the same households, so our data constitute a panel of villages but not of households. Baseline and follow-up samples were drawn independently of each other, and independently of program participation. The RCT was conducted in poor rural areas where agriculture and animal husbandry represented the bulk of the local economic activities.

Borrowing was not common and at baseline just above one household every ten had any outstanding loans. The intervention aimed at increasing access to microcredit in program areas through the entry of two MFIs, the Amhara Credit and Savings Institute (ACSI) in Amhara and the Oromiya Credit and Savings and Share Company (OCSSC) in Oromiya. In several respects, both institutions were typical micro-lenders that granted small loans to small and self-formed groups of borrowers who took joint responsibility for loan repayment. Loan eligibility was supposed to be selected on the basis of several criteria, of which the presence of a viable business plan and poverty status were the more salient ones. Lending was supposed to especially target women, although guidelines in this regard were loose, and indeed we find that a majority of loans were initiated by men. In addition, unlike many micro finance institutions (MFIs), OCSSC and ACSI often required some forms of collateral from borrowers (as in the program studied in Attanasio et al. 2013), making it harder for the very poorest households to have access to loans. Both ACSI and OCSSC started lending shortly after the baseline survey and continued to do so until the time of the endline survey, after about three years. Our RCT is thus characterized by one of the longest time spans between

\footnotetext{
${ }^{1}$ Pronyk et al. (2006) randomized access to loans for women (together with a gender and HIV training curriculum) in a randomly chosen half of study villages in rural South Africa. However, only eight villages were included in the study, and key results are not based on a treatment-control comparison but rather on comparing women who self-selected into the program in treated areas with others from control communities matched based on observed characteristics.
} 
pre and post-intervention surveys among those cited earlier.

We will show that borrowing increased substantially more in treated relative to control communities, both on the intensive and the extensive margin. In areas where ACSI/OCSSC had been assigned to enter, borrowing prevalence increased by about 25 percentage points relative to control areas, and the average amount of outstanding loans was almost twice as large. Almost all the increase in borrowing was due to micro-loans from ACSI/OCSSC, suggesting that rather than displacing other forms of pre-intervention borrowing, the introduction of micro-lending led to substantial relaxation of credit constraints. In addition, borrowing from other MFIs changed very little over time, so what we identify is the impact on first-generation borrowers from micro-lenders, similar to Crépon et al. (2011).

Despite the large increase in borrowing, we find that for a large majority of socio-economic outcomes the null of no impact cannot be rejected, although in several cases the point estimates are substantively large but imprecisely estimated. For instance, we estimate that in areas assigned to microcredit a $95 \%$ confidence interval for the value of livestock owned is consistent both with a $25 \%$ increase and a $10 \%$ decrease relative to communities assigned to control. Similarly, the 95\% confidence interval for the impact on revenues from self-employment activities is consistent with a doubling of revenues or a $15 \%$ decrease relative to control areas. In several cases, the width of several confidence intervals is thus large enough to be consistent with both substantial improvements and large declines. On the other hand, our estimates are sufficiently precise to reject (at the $5 \%$ level) the null that assignment to the microcredit treatment increased the prevalence of new non-farm business creation by more than 1.4 percentage points relative to control areas.

Such inconclusive results are at least partly due to insufficient power, especially for outcomes such as revenues and profits that are hard to measure and characterized by large variances. We also highlight that, unlike all the other RCTs cited earlier, our data do not include information on consumption. This is unfortunate, because in other contexts it has been shown that access to microcredit, while leaving aggregate consumption largely unchanged, can increase consumption of durables while decreasing expenditures in 'temptation goods' such as cigarettes or alcoholic beverages. Due to data limitations we cannot document if similar patterns emerged in our study areas.

The rest of this paper is organized as follows. Section 2 describes the details of the intervention and the study design. Here we also discuss how the micro-lenders partly deviated from the experimental protocol, starting operations in some areas assigned to control while doing the opposite in 
some PAs assigned to treatment. Because such deviations from protocol potentially invalidate the exogeneity of treatment, we focus on intent-to-treat estimates, interpreted as impacts of assignment to microcredit. We include the details of the estimation strategy in Section 3, where we also describe the results. Finally, Section 4 concludes, after discussing our findings in relation to the literature.

\section{Study Design and Baseline Summary Statistics}

The study was implemented over a large geographical area in rural western Ethiopia, spread over 133 administrative units called kebeles or 'peasant associations' (PAs) from two 'zones' of the Oromiya region and two zones in the Amhara region, about 300-400 Kms. respectively west and north of the capital Addis Ababa, see the map in Figure 1. ${ }^{2}$ The main sources of income in study areas were agriculture and animal husbandry, in some cases supplemented with small-scale retailing activities or day labor. Unlike the arid eastern regions, the study locations usually benefit from plentiful precipitation, with an average of 1,200-2,000 millimeters of rainfall per year in 1971-2000 in both regions.

The study area was identified in the context of the expansion of micro-credit and FPPs supported by the David and Lucille Packard Foundation Population Program. The expansion was implemented in Oromiya by the Oromiya Credit and Savings Share Company (OCSSC) and the Oromiya Development Association (ODA) and in Amhara by the Amhara Credit and Savings Institute (ACSI) and the Amhara Development Association (ADA). The research team identified 191 villages in 78 PAs where OCSSC and ODA planned to expand in the coming years in Oromiya and 162 villages in 55 PAs where ACSI and ADA planned to expand.

In each of the 133 study PAs, interview teams obtained a complete list of all villages with an estimate of the total number of households in each village. If the PA had more than 400 households, three villages were randomly selected. If the PA had fewer than 400 households, two villages were selected at random. Within each selected village, interview teams conducted a complete

\footnotetext{
${ }^{2}$ Peasant associations are the smallest local unit of government in Ethiopia and comprise a number of villages. PAs are then grouped into 'woredas', which are then aggregated into 'zones', and zones into regions (Ofcansky and Berry 1991). The eight study woredas in Oromiya are Anfillo, Ayra Guliso, Haru, Mana Sibu, Nedjo and Seyo in West Wellega zone, and Metu and Chora in Illubabor zone. In Amhara, they are Bugna, Gidan and Meket Delanta in the Semien (or 'North') Wollo zone, and Metema, Chilga, Alefa Takusa, and Lay Armachiho in North Gonder zone.
} 
enumeration of households, and a random sample of households was chosen to participate, with interviews completed between January and May of 2003. In all, 6,412 households were interviewed at baseline, of which 3,196 in Amhara and 3,216 in Oromiya. The sample is not self-weighted and therefore sampling weights are required to produce unbiased estimates of population statistics. We use sampling weights throughout the paper, although the un-weighted results are generally very similar.

\subsection{Experimental Design}

The data used in this paper were collected as two independent cross-sections from the same villages in 2003 and 2006 as part of the evaluation of a cluster randomized controlled trial (RCT) conducted by Family Health International. The main focus of the RCT was on fertility choices and contraception, and its primary purpose was to determine whether linking microcredit with family planning services could increase the use of contraception beyond what each program could accomplish separately. As part of this evaluation, after the completion of the baseline survey the 78 PAs in Oromiya were randomly scheduled to see the introduction of microcredit (20 PAs), family planning services (18), both (20) or neither (20). The 55 PAs in Amhara were assigned as follows: microcredit (14), family planning services (13), both (15), or neither (13). Randomization into the three treatment groups and one control group was completed independently in each of the two regions, with no further stratification. Random assignment to experimental arms was conducted at the PA level, so that all sample villages and households from the same PA were assigned to the same group. ${ }^{3}$ Randomization produced roughly 800 households in each of the four original treatment groups.

The community-based FPPs were based on women from local communities trained and remunerated to make house-to-house visits, provide fertility-related information and offer contraceptives at no cost. In areas where both services were introduced, credit officers also provided information on family planning methods to women borrowers (but did not offer contraceptives). In principle, the FPPs could have had an impact on economic activities via a change in family planning. However, Desai and Tarozzi (2011) show that the programs (both in isolation and when jointly present) failed to modify contraceptive behavior, and were only weakly associated with changes in

\footnotetext{
${ }^{3}$ The random assignment of PAs to treatment arms was conducted using statistical software by a bio-statistician at Family Health International, North Carolina, United States.
} 
fertility. ${ }^{4}$ For this reason, in this paper we choose to focus only on the impact of increased access to microcredit, although in our preferred estimates we also control for the presence of FPPs, in isolation or in addition to micro-lending, see Section 3 for details.

Both ACSI and OCSSC, the two micro-finance institutions (MFIs) that partnered with Packard for this evaluation, are development-oriented institutions with strong links to the Government. Prior to the end of the civil war in 1991, all banking and insurance activities were monopolized by the Ethiopian government. Proclamation No. 84/94 was later issued allowing private domestic investors to also participate in these activities, but the government maintained a strong involvement in the evolution of Ethiopian MFIs, which overall operate is a non-competitive environment (Wolday 2002). At the time of writing, government-supported micro-enterprise lending program encompasses about 30 MFIs registered, licensed, and regulated by the National Bank of Ethiopia, including ACSI and OCSSC. ${ }^{5}$ ACSI began as a project of the NGO Organization for the Rehabilitation and Development in Amhara, and was officially established as a microfinance institution in 1997. ${ }^{6}$ Its stated mission is to "improve the economic situation of low income, productive poor people in the Amhara region through increased access to lending and saving services". OCSSC was also established in 1997, and was born out of the Oromiya Rural Credit and Savings Scheme Development Project, with the stated mission to "provide need-based micro financial services to strengthen the economic base of the low-income rural and urban people in Oromiya through increased access to sustainable and cost efficient financial services".

Both ACSI and OCSSC operated on the basis of group lending. Small and self-formed groups of borrowers, who took on collective responsibility for repayment of loans, were selected on the basis of several criteria, of which business plan and poverty status were the more salient ones. Loans were made for one year at interest rates reflecting market conditions. Based on OCSSC and ACSI records, the interest rate in 2002-2003 was $12 \%$ per year on average. Credit officers helped fill out loan applications and monitored the groups. Borrowers were expected to make regular deposits and repayments. Both OCSSC and ACSI reported repayment rates higher than $95 \%$ in the years before the intervention. In both regions, the credit program expansion was supposed to target poor women borrowers, but in reality no strict guidelines about the gender of the borrowers was issued. For this reason, as we will show, loans were often granted to individuals of both genders.

\footnotetext{
${ }^{4}$ The most likely reason is that the FPP did not provide injectables (the main contraceptive method in these regions), although referrals to clinics were provided.

${ }^{5}$ See http://www .aemfi-ethiopia.org/site/membership.html.

${ }^{6}$ For more information see http://www.acsi.org.et.
} 
The guidelines of both micro-lenders mentioned that no collateral was required in order to have access to loans, although our post-intervention data suggest otherwise, with a majority of borrowers indicating that they had been asked for collateral.

The micro-lenders were directed to start lending in program areas shortly after the baseline survey, and to continue to do so thereafter. Service data collected in study PAs to verify program implementation indicate that by the end of 2003 ACSI/OCSSC were already granting loans in $63 \%$ of treated PAs, and the proportion grew to $82 \%$ by the end of 2004 . In a large majority of treated communities, program exposure was thus as long as 2-3 years.

Before discussing the baseline summary statistics, it is important to highlight limitations of this study related to statistical power. Although both pre and post-intervention surveys recorded a wealth of information about households' socio-economic conditions and income-generating activities, sample size was determined specifically to ensure sufficient power to detect changes in rates of contraceptive usage, which was initially the key outcome of interest. ${ }^{7}$ An implication of this is that statistical power was ex-ante relatively low for outcomes such income or wealth indicators, outcomes which are usually characterized by large variability and measurement error. We will return to this point when we discuss the results.

\subsection{Baseline Summary Statistics}

The randomization was overall successful at producing balance in a broad range of statistics among the four original treatment groups (Desai and Tarozzi 2011, Table 2). Because in this paper we focus on the impacts of micro-credit, in Table 1 we show summary statistics calculated separately for communities where micro-lenders were assigned to start operating ('assigned to treatment') versus others assigned to receive either FP programs or no intervention ('assigned to control'). Overall, the figures show good balance, with differences between arms generally small and significant at standard levels for only one of 35 variables, although the joint null of equality is rejected at standard levels $(\mathrm{p}$-value $=0.0025)$.

The summary statistics document the poor overall socio-economic status of sample households. Households were large (about 5 members on average) and most household heads had low levels

\footnotetext{
${ }^{7}$ Sample size was determined to ensure an $80 \%$ probability of rejecting the null of no effect at the $5 \%$ significant level, assuming a baseline contraceptive rate of 6\% (estimated from the 2000 Demographic and Health Survey of Ethiopia), an intra-class correlation of 0.05 and a 12 percentage points difference in contraceptive behavior between any two of the four experimental arms.
} 
of schooling. Most study communities were remote, on average more than an hour away from the nearest market or health center. More than a quarter of households used surface water (from rivers, lakes etc.) as main source for drinking needs. Food scarcity was also common, with respondents reporting on average more than two months of insufficient food in a typical year.

Agriculture was the main economic activity for almost $90 \%$ of households. In control areas revenues from crops during the 12 months before the interview were 203 Birr on average (or about 90 USD using the PPP exchange rates in World Bank 2008), while total expenditures were 90 Birr. Animal husbandry was also important, both as an income-generating activity and as a form of asset accumulation: in control areas, on average households owned almost three large animals such as cows or oxen, the total value of livestock was 1500 Birr (about 670 USD, more than seven times the average revenues from crop cultivation) and sales of animals amounted to 160 Birr in the previous 12 months. Other sources of income included wage labor (174 Birr per household on average during the previous 12 months), transfers in cash or kind (115 Birr) and sales from non-farm business activities (310 Birr), although households only owned 0.1 such activities on average.

Baseline information also shows that borrowing was very limited in the area. Only $13 \%$ of households borrowed in Control areas, and the average amount of outstanding loans (including zeros for non-borrowing households) was less than 40 Birr. Most households borrowed from informal sources, while less than $3 \%$ had loans from formal institutions such as banks and cooperatives. Micro-finance institutions or revolving credit associations were also rare, with about two percent of sample households having funds from such sources.

In principle, the very low prevalence of borrowing at baseline may also be consistent with low demand for credit, but several indicators suggest that limited access to credit had negative implications for households' income generating activities and consumption smoothing ability. First, we have seen that on average households experienced more than two months of insufficient food. Indeed, only $27 \%$ of respondents said that their household always had enough to eat, while $45 \%$ stated that food was not sufficient for 2-3 months in a typical year and about one quarter said that food scarcity was a problem for four months or longer. Access to credit may have helped households to smooth consumption seasonality. Second, limited access to credit was mentioned among the three most important factors limiting income growth in agriculture and non-farm business activities by about $20 \%$ of households involved in such activities (figures not reported in the table). ${ }^{8}$ Limited

\footnotetext{
${ }^{8}$ Insufficient credit was not listed as a possible option limiting income growth in livestock activities, so we do not have clear information about the role of credit constraints for this activity, although we know that insufficient grazing
} 
access to credit may also have contributed to the fact that only $11 \%$ of households had any non-farm business, although our data do now allow us to test this conjecture.

\subsection{Deviations from the Experimental Protocol}

We have seen that the results in Table 1 show a good degree of balance in observed characteristics between areas assigned to treatment and control. However, the implementation agencies did not always comply with the experimental protocol. In fact, actual treatment coincided with the randomly assigned treatment in only 104 of the 133 PAs, that is, in $78 \%$ of cases. Specifically, 8 of the 69 PAs where micro-credit was supposed to be introduced did not see it happening, while ACSI/OCSSC started to operate in 15 of 64 areas where they had not been assigned to do so. ${ }^{9}$

In Table A.4 we show the results of a linear probability model where we regress a dummy equal to one if the household resided in a PA where micro-lending was actually introduced on a dummy equal to one when the PA was assigned to micro-lending and a list of observed household characteristics. Although as expected assigned treatment is the strongest predictor of treatment, a number of other coefficients are large and significant at standard levels. In particular, borrowing from informal sources decreases the predicted probability of treatment by 16.5 percentage points ( $\mathrm{p}$-value $<0.001$ ), and income from wages or transfers also decreases significantly such probability, although the corresponding slopes are very small. A joint test of significance of all slopes except assigned treatment is rejected at the $5 \%$ level $(p$-value $=0.011)$.

The results of the regression do not show an overall unambiguous pattern of purposely selective program placement, for instance towards areas that were richer or poorer, or towards areas with more or less access to formal credit. Despite this, in order to avoid potential bias from endogenous deviations from the assigned program placement, in the rest of the paper we rely on intent-to-treat estimates, see Section 3 for details. In the Appendix we also show the results of two-stage least square estimates where we use assignment to treatment of PAs to instrument for actual (potentially endogenous) treatment of study PAs. Random assignment ensures the exogeneity of the instrument, while the relatively limited departures from the experimental protocol rule out concerns related to weak instruments.

land was mentioned as the key limiting factor in $83 \%$ of cases.

${ }^{9}$ In the end, both microfinance and FPP were introduced in 43 PAs, microfinance only was introduced in 33 , FPP only in 20 and neither in 37. 


\subsection{Endline Survey and Attrition Concerns}

The endline survey was completed in March-July 2006, approximately three years after the preintervention survey. At this time, a total of 6,263 households were interviewed, of which 3,059 in Amhara and 3,204 in Oromiya. As explained earlier, the endline sample was drawn independently from baseline, drawing randomly from a new census conducted in the same study villages in 2006. This does not allow us to evaluate attrition in a straightforward way, with potentially important implications for the interpretation of the results. On the one hand, our focus on intent-to-treat estimates (see Section 3) still allows us to interpret the results as causal impacts of assigning communities to receive specific interventions, regardless of the actual implementation of such interventions (at the PA level) and regardless of actual take up conditional on implementation (at the household level). On the other hand, the interpretation of the results would change if the interventions had an impact on the composition of the surveyed sample. This may have happened if the interventions led to differential migration into or out of study areas, or to differential survey response rates, with unclear consequences for the results. For instance, if assignment to micro-credit reduced outmigration due to improvements in local economic conditions, the estimates would confound impacts on outcomes conditional on residing in a treatment community with impacts on the probability of residing in such community.

Despite these considerations, our data suggest (albeit indirectly) that differential migration or response rates are unlikely to raise important concerns for the interpretation of the results. As a first check, we use information about the length of time spent by sample households in their village of residence. Only 80 of 6,263 respondents in the post-intervention survey (1.3\%) reported having lived in their village for less than four years (recall that the baseline was completed three years earlier). Information on the reason for migration is available for only 46 of these households, but in no case was the reported reason directly related to the availability of microcredit, although 23 respondents reported migration was due to 'work'. Of these 23, 18 moved into areas were microcredit was not introduced, so most of these re-locations were not due to earning opportunities opened up by the increased availability of credit.

Next, in Appendix Table A.5 we evaluate whether either actual or assigned treatment were systematically associated with a few household characteristics - such as duration of current residence, the number of adults in the households or the gender or education of the head-that were least likely to have changed directly as a consequence of the interventions. Significant changes over 
time in these characteristics could signal differential migration or survey response, but we find little evidence of it. The null of equal changes across treatment arms is only rejected (at the $5 \%$ level) for the number of adults in the household, and even in this case the differences across arms are not large, with the means ranging from 2.4 to 2.7 .

Overall, we thus conclude that migration or differential survey responses are unlikely to be key drivers behind our results, although the lack of a true panel of households does not allow us to rule out these concerns conclusively.

\section{Estimation Methodology and Results}

The lack of a panel of households does not allow us to look at changes in outcomes at the household level, but because the same villages were surveyed before and after the intervention we can control for the presence of time-invariant location-specific fixed effects. Throughout the paper, we define treatment at the level of the unit of randomization, that is, the PA. As we mentioned earlier, in a number of PAs the actual program implementation differed from that scheduled to take place according to the randomized assignment. In the rest of the paper we focus on intent-to-treat (ITT) estimates, by regressing outcomes of interest on PA-specific dummy variables for randomly assigned treatment. For a given outcome $y$, the equation being estimated is thus the following:

$$
y_{p i, t}=\alpha_{p}+\left(\beta_{\text {Post }}+\beta_{M F} M F_{p}+\beta_{F P} F P_{p} \times\left(1-M F_{p}\right)+\beta_{\text {Both }} \times F P_{p} \times M F_{p}\right) \times \text { Post }_{t}+u_{p i, t}
$$

where $y_{p i, t}$ denotes the outcome for household (or individual) $i$ in PA $p$ and time $t$ (where $t=0$ denotes baseline and $t=1$ follow-up), $\alpha_{p}$ is a PA fixed effect and Post $_{t}, M F_{p}$ and $F P_{p}$ denote binary variables equal to one when, respectively, $t=1$ and when microcredit or FPP were randomly assigned to be introduced in PA $p$. The residual $u_{p i, t}$ is allowed to be correlated within PA, so all standard errors and tests will be robust to intra-PA correlation. The intent-to-treat parameter $\hat{\beta}_{M F}$ is thus the main object of interest. Equation (1) also controls for assignment to FPP, either in isolation or in addition to micro-lending. The coefficient $\beta_{F P}$ measures the impact of assigning a community to receive FPPs without micro-lending (that is, when $F P_{p}=1$ and $M F_{p}=0$ ), while $\beta_{\text {Both }}$ measures any differential impact of assignment to micro-lending when FPPs were assigned to be introduced as well (that is, $F P_{p}=1$ and $M F_{p}=1$ ). In light of the fact that the FPPs were not effective at changing contraceptive usage (the main outcome initially targeted by the study, see Desai and Tarozzi 2011) our prior was that $\hat{\beta}_{F P}$ and $\hat{\beta}_{\text {Both }}$ would be generally small and not statistically significant. This prediction is mostly but not always borne out in the data. Still, 
because the main objective of the paper is to gauge the impact of microfinance we choose to focus

on $\hat{\beta}_{M F}$, although we report the full results in the Appendix, where we also show the estimates when the presence of family planning services is ignored (that is, when we impose $\beta_{\text {Both }}=\beta_{F P}=0$ ).

If the experimental design had been followed perfectly (a condition that fails in our empirical context), the ITT would identify the average impact of giving access to micro-lending in the study area, regardless of actual household borrowing. ${ }^{10}$ However, the potentially endogenous deviations from experimental protocol mean that the ITT in (1) only identifies the impact of assigning communities to the treatment, regardless not only of actual borrowing but also of actual program implementation in the field. The impact of treatment assignment remains of policy interest, given that any program expanding access to microfinance will likely have to contend with the unwillingness or inability of the MFI to enter certain markets. Throughout the paper we thus focus on the reduced form impact of program assignment.

As an alternative, we could have estimated a model analogous to (1) using two-stage least squares (2SLS), replacing the dummies for assigned treatment with dummies for actual treatment and using the former exogenous variables to instrument for the potentially endogenous latter ones. We do not pursue this strategy here to make our results more easily comparable to the other RCTs in the special issue of this Journal, but the interested reader can find the 2SLS estimates in the Appendix. ${ }^{11}$

\subsection{Impact on Borrowing Behavior}

To estimate the impacts on borrowing behavior we rely on household survey data collected before (2003) and after (2006) the intervention that reflect self-reported information on loans at the time

\footnotetext{
${ }^{10}$ Heckman et al. 1999, p. 1903 define ITT as the 'mean effect of the offer of treatment'.

${ }^{11}$ Because randomly assigned treatment status is an exogenous and strong instrument for treatment, 2SLS will estimate the ITT impact of providing access to micro-credit if program impact is homogeneous across areas. However, in the common situation where program impacts are heterogeneous, and under the plausible assumption that assignment to a given treatment (weakly) increases the probability of that treatment in all PAs, 2SLS will only estimate a local average treatment effect (LATE, Imbens and Angrist 1994). The LATE can thus be interpreted as the impact only for 'complier' PAs, defined as those that saw the introduction of micro-lending only because they were assigned to it. Under the assumption of no externalities or general equilibrium effects across PAs, one could also estimate the average impact on households who actually borrowed by dividing the 2SLS estimate by the fraction of borrowers. However, the introduction of microfinance is likely to generate general equilibrium effects that will affect non-borrowers as well (Kaboski and Townsend 2012, Buera et al. 2013) so for this parameter assigned treatment, while still a strong instrument for borrowing behavior, would likely fail the exclusion restriction.
} 
of the surveys. In contrast, we have no detailed information provided directly by the MFIs about variables such as total loans disbursed or clients served by PA/year. However, service data collected in all PAs to verify the extent to which program implementation deviated from the experimental protocol indicate that by the end of 2003 ACSI/OCSSC were already granting loans in $63 \%$ of the PAs where they eventually entered before the follow-up survey, and the proportion grew to $82 \%$ by the end of 2004. In a large majority of treated communities, program exposure was thus as long as 2-3 years.

In Table 2, we demonstrate that the intervention led to substantive and statistically significant increases in borrowing. The figures in column 1, panel A, show that assignment to MF increased the fraction of households with any outstanding loans from ACSI/OCSSC by 25 percentage points relative to control areas, where less than $6 \%$ of households borrowed from these sources. ${ }^{12}$ The estimate is precise and the null of no impact is rejected at the $1 \%$ level. In columns 7 and 8 we show the corresponding estimates when we use assigned treatment status dummies (interacted with Post) as instruments for actual treatment status (again interacted with Post). As expected, the instruments are strong and the 2SLS estimate is substantively larger, indicating a 36 percentage point increase in borrowing prevalence in treated areas. As we indicated earlier, in the rest of the paper we only focus on the OLS-ITT estimates, while including the 2SLS estimates in the Appendix.

We find no evidence of crowding out of other forms of borrowing (column 2-4): the frequency of loans from NGOs, banks and cooperatives increased by 2-3 percentage points relative to control areas, that of loans from informal sources was barely affected, and neither ITT is significant at standard levels. As a consequence, the impact on loans from the micro-lenders is virtually identical to the overall impact on the frequency of borrowing (column 5). We also see that, despite the lack of strict guidelines about targeting women for loans, female borrowing saw very substantial impacts: while in control areas less than $6 \%$ of households had loans initiated by women, the ITT estimates show an 8 percentage points larger prevalence in treatment areas. ${ }^{13}$

\footnotetext{
${ }^{12}$ The figure of 0.06 represents the fraction of households borrowing from 'revolving credit associations' (RCA) at endline in areas assigned to receive neither MF not FPP. In the section of the post-intervention questionnaire were outstanding loans were listed, borrowing from ACSI/OCSSC was coded as borrowing from RCAs and so we use the two terms as identical, although, especially at baseline, in some cases the loans may have been obtained from sources different from ACSI/OCSSC. In any case, our data indicate that the large majority of loans from RCAs at follow-up were indeed from ACSI/OCSSC.

${ }^{13}$ Note also that, because the follow-up was conducted in the same villages as the baseline, model (1) can be
} 
The estimates in the bottom panel B of Table 2 show that not only the frequency of borrowing increased, but the amounts involved were substantial. The estimated ITT was 368 Birr (standard error 84), that is, more than one-and-a-half times the average revenues from crop sales in control areas at baseline and about one fourth of the average value of livestock owned (see Table 1). Consistent with the results on borrowing prevalence, the impact on borrowing from ACSI/OCSSC is almost identical to that on total borrowing, with no evidence of important changes in loans from other sources. The mean amount of women-initiated loans increased by 134 Birr relative to control areas, from an average close to zero at baseline.

When we look only at households who borrowed from ACSI/OCSSC (results not in table), we estimate that the median loan at follow-up in treated areas was approximately 1,200 Birr (about 500 USD), with only about $10 \%$ of loans smaller than 700 Birr and about $10 \%$ larger than 2,000 Birr. To put these figures in perspective, the official poverty line, expressed in total consumption per adult/year in 2006, was close to 1,500 Birr, while the mean amount of total outstanding loans among households who borrowed (from any sources) at baseline in control areas was about 300 Birr (in 2006 units). Our data thus show considerable increases impacts in both the extensive and the intensive margin of borrowing.

As we discussed earlier, in a subset of PAs the micro-lending operations were accompanied by the introduction of community-based FPPs, conducted by independent organizations. As indicated in model (1), we always control for the presence of such programs, either in isolation or in addition to micro-credit. We show the full results in Appendix Table A.6. As expected, in all regressions the coefficients $\beta_{F P}$ and $\beta_{B o t h}$ are not significant at standard levels, although in some cases the point estimates are not small. In Appendix Table A.6, we also show that ignoring the presence of such programs leave the results substantively unchanged, although the estimated ITTs become smaller for borrowing prevalence and larger for amounts borrowed.

In Appendix Table A.7 we show the results of a regression where we analyze what predicts borrowing from micro-lenders in areas where access to this form of credit was actually introduced. Of course these estimates are not to be interpreted causally because all regressors are likely endogenous, being possibly correlated with sources of unobserved heterogeneity such as entrepreneurship, impatience and risk aversion among the others. Still, we chose regressors that were unlikely to estimated using village, rather than PA, fixed effects. In Appendix Table A.6 we show that the two sets of results are almost identical in terms of both point estimates and standard errors, and so in the rest of the paper we will only focus on the PA-fixed effects results. 
have been affected by the availability of credit, so that at least we can exclude reverse causality from borrowing to the covariates. Recall also that we do not have a panel of households, so we do not have any household-specific data recorded for these same households before the intervention. We also included in the regressions PA fixed effects, so that the estimates control for all PA-level characteristics that may enter in an additive, linear way in the prediction. The results show that a number of variables are very strong predictors of borrowing from micro-credit. In particular we find evidence that households with low socio-economic status were less likely to borrow from ACSI/OCSSC: everything else being the same, the presence of a head with no formal schooling reduces the likelihood of borrowing by 7 percentage points (p-value 0.002 ), while the predicted probability increases by 2 percentage points for every additional hectare of cultivable land $(p<0.01)$ and for every additional sleeping room in the household's dwelling ( $p=0.103)$. Households that have resided in the current location for less than four years were 14 percentage points less likely to borrow $(p=0.034)$. Overall, this is consistent with ACSI/OCSSC lending preferentially to households more likely to be able to repay the loans and possibly more likely to offer collateral. One additional interesting observation is that households who had a non-farm business that started at least four years before the follow-up (that is, before the intervention) were six percentage points more likely to borrow $(p=0.013)$.

Respondents reported that a large majority of loans from ACSI/OCSSC were utilized for productive purposes. Of a total of 1,682 micro-loans at follow-up, 1,388 (83\%) were reported as having been initiated to pay for 'working capital' or 'basic investment'. Such categories encompassed production-related items such as wages for hired labor, rents for land and equipment, cost of seeds, fertilizers and pesticides, fees for veterinary services, purchase of animals, land, equipment etc. In contrast, only 25 loans were initiated to repay other loans, and a total of 144 (9\%) were used to pay for consumption, schooling or ceremonies. We also find that most loans were initiated to fund crop cultivation or animal husbandry, with $80 \%$ of the 1,388 loans used for working capital or investment in these sectors and only 235 (17 percent) used for 'trading and services'. The remaining 40 loans were used for hard to categorize agricultural and non-agricultural 'processing' and for 'production'.

\subsection{Impact on Households' Economic Activities}

Next, we turn to the analysis of impacts of ACSI/OCSSC operations on households' economic activities. Both baseline and follow-up surveys included information on sales as well as input purchases for farm and livestock activities and for non-farm self-employment businesses. No information was 
collected on family employment or home consumption, so we cannot estimate a measure of profit. We focus then on measures of 'net sales', calculated as differences between yearly revenues and input purchases. Expenditures and sales related to these activities were recorded with a 12-month recall period, see Appendix A.1 for details. The one-year reference period likely reduced concerns about seasonality, but it may have exacerbated recall errors that are common in context such as ours were record-keeping is rare. de Mel et al. (2009) find that in a sample of micro-enterprises in Sri Lanka reports were similar when using a 12-month recall as compared to the sum of monthly data collected four times during the year, although they also find evidence of mis-reporting with both methodologies.

In panel $\mathrm{A}$ of Table 3, we show that none of the impacts on non-farm business activities was significantly different from zero at standard levels, although some of the estimates are large in magnitude. A key result is that we find no evidence that the substantial increase in borrowing documented earlier led to non-farm business creation in areas assigned to treatment. The ITT is actually negative for the fraction of households with a non-farm business, or with a female-led nonfarm business, or for the fraction that started a business in the previous three years (columns 1-3). Although the confidence intervals for these variables always include positive values, the estimates are sufficiently precise to reject the null of an ITT larger than 1.4 percentage points for the probability of non-farm business creation during a three-year period that encompassed approximately the time interval between baseline and endline surveys (the confidence interval is -0.049 to 0.013 ).

When we look at non-farm business-related monetary outcomes we find that, while again not significant at standard levels, the impacts are large in magnitude, see columns 4 to 7 . The ITT for 'net revenues' (the difference between sales and monetary costs in the previous 12 months) is 526 Birr with a standard error of 403, so that the upper bound of the $95 \%$ confidence interval (1316 Birr) is almost as large as the average value of livestock in control areas at baseline, while the lower bound $(-264)$ is almost one fifth of such value in magnitude.

In panel B we show estimated ITT impacts on crop cultivation and livestock activities during the 12 months before the survey. The ITT for revenues from the sale of crops is 63 Birr, or $9 \%$ of the endline mean in control areas, while the standard error is more than three times as large, so the $95 \%$ confidence interval is very wide ( -366 to 492 Birr). In contrast, the ITT for the total monetary costs incurred for crop cultivation is significant at the $5 \%$ level, and the point estimate is very large (154 Birr), more than $80 \%$ of the average for this value in control areas at follow-up. However, this result is difficult to interpret because we do not have information on total quantities 
produced or consumed, so such costs refer to inputs used to produce crops destined to both the market and self-consumption. In column (3) we estimate the ITT for 'net sales' estimated as the difference between total cash sales and total crop-related expenditures multiplied by the share sold, see Appendix A.1 for details. Such impact is close to zero, although the $95 \%$ confidence interval is very wide (about \pm 400 Birr). The ITT for the amount of land cultivated is similarly close to zero and imprecisely estimated, although we can reject the null that assignment to microcredit led to increases larger than one quarter of the average area cultivated in control areas at follow-up.

Columns 5 to 7 of panel B show that areas assigned to micro-loans saw relatively larger increases in the stock of animals owned as well as in the value of their sales. The estimated impact on the value of livestock owned is large (206 Birr), but the standard errors are even larger so the $95 \%$ confidence interval includes negative ITTs as large as $20 \%$ of the mean livestock holdings at baseline in untreated areas, and positive values almost half as large as that. The ITT for the value of sales is moderately large (77 Birr) and is significant at the 5\% level, with the lower bound of the $95 \%$ confidence interval positive but close to zero and the upper bound equal to about $10 \%$ of baseline holdings in control areas.

In Table 4 we analyze the ITTs on aggregate measures of income from self-employment activities as well as from other income sources. Overall, areas assigned to microcredit saw substantively larger increases in both revenues and expenses for self-employment activities, although the estimates are noisy and the null of no impact cannot be rejected at standard levels. The point estimates of the ITT is 712 Birr, almost exactly half of mean revenues in control areas. The confidence interval is very wide and ranges from -227 to 1651 Birr. The ITTs for total costs and 'net revenues' for self-employment activities (the latter calculated as the difference between total revenues and total costs) are also large but not significant. In particular we estimate an average impact on net revenues of 513 Birr (or $68 \%$ of the average in control areas) but once again the $95 \%$ confidence interval is wide ( -332 to 1358 Birr). The magnitude of the ITT for total production costs (199 Birr) is 54\% of the ITT for amounts borrowed from ACSI/OCSSC. Although the estimate is noisy (the standard error is 156 Birr) this is consistent with loans being initiated in large part for productive purposes, as indicated by respondents.

The impact on wages was also positive (49 Birr) but not significant. Given the standard error (84) we can reject negative impacts larger than 116 Birr or positive impacts larger than 214 Birr. Impacts on transfers from any source or 'other income' are also not significant although for these variables the point estimates and the standard errors are small enough that substantive impacts 
can be ruled out. That transfers were not affected is interesting, because it suggests that the large increase in borrowing documented in Table 2 did not come at the expense of reduced transfers from any existing transfer network that pre-dated the program. This finding is also consistent with the earlier result that the introduction of micro-finance did not appear to crowd out existing borrowing from informal sources.

Because we do not have access to panel data our ability to evaluate impacts heterogeneous by pre-intervention characteristics is limited. Despite this, we can use quantile regression to study whether different part of outcome distributions were affected differently. This is potentially important, because other evaluations have found that impacts on income-generating activities were concentrated in the upper tail of the distribution, see Banerjee et al. (2013) or Angelucci et al. (2014). We focus on outcomes for which the OLS regressions showed substantive (if not statistically significant) impacts. For each outcome, we estimate quantile regressions at nine equally spaced quantiles from 0.1 to 0.9 , using the same right-hand side variables as in model (1) but replacing the PA fixed effects with a constant and three arm-specific dummies. ${ }^{14}$ We show the results in the eight graphs in Figure 2, together with 90\% confidence bands estimated using 250 block-bootstrap replications using PAs as blocks.

When we look at non-farm business net sales (panel A), we find that the low prevalence of this kind of business causes most ITTs to be close to zero. The only exception is for the 9th decile, where the impact is large and negative (close to -200) but not significant. It may be recalled that the OLS regressions in Table 3 showed large and positive (although not significant) average impacts. It turns out that the latter were completely driven by a handful of outliers: if we exclude eight observations larger than 50,000 Birr, the average impact from estimating model (1) with OLS becomes negative as well ( -76 , standard error 96, hence not significant). Overall, this confirms that ACSI/OCSSC did not substantively help the creation of the growth of non-farm businesses in study areas.

When we look at crop cultivation (panels B to D), we find that impacts on crop sales (either total or net of costs) were relatively small and not significant throughout the distribution. The large positive average ITT estimated with OLS for crop-associated costs was driven by increases in the part of the distribution to the right of the median: the quantile effects are all positive and

\footnotetext{
${ }^{14}$ The inclusion of the many PA-specific dummies generates problems of convergence in the solving algorithm for the quantile regression in some cases, so we focus on the simpler model which anyway estimates consistently the ITT of program assignment.
} 
increasing above the 4th decile, and they are all significant above the median at the $10 \%$ level (recall that we always display $90 \%$ confidence bands). The impact at the 90th percentile is close to 300 Birr, although the $90 \%$ bands range from close to zero to above 500 Birr.

In panels $\mathrm{E}$ and $\mathrm{F}$ we look at quantile regressions for the value of livestock owned and the value of sales. The OLS regressions in Table 3 showed that both ITTs were positive and relatively large, although only the latter was significant, at the $5 \%$ level. The quantile regressions show positive impacts for all deciles but the first, with larger impacts for higher deciles. However, the estimates for the highest deciles are also noisier, so the null of no impact is only rejected (at the $10 \%$ level) for the deciles from the 4 th to the 7 th. In contrast, impacts on livestock sales are more clearly concentrated in the right tail of the distribution, also because the fraction of households with any sales is sufficiently low that deciles up to the median remain equal to zero. The ITTs are in a 150-200 Birr range and not significant for deciles 6 and 7 and between 200 and 300 Birr for the 8th and 9th decile of the distribution, although for both these latter deciles the lower bound of the $90 \%$ confidence interval is close to zero.

Finally, in panels $\mathrm{G}$ and $\mathrm{H}$ we look at aggregate measures of revenues (gross or net) from all self-employment activities. The estimates are almost all positive but noisily estimated, with overall evidence of larger impacts above the median. To sum up, the quantile regressions suggest that areas assigned to the microcredit experimental arm saw overall increases in earnings from selfemployment activities which, however, mostly affected the right tail of the distributions. It should also be kept in mind that, as for the case of the ITTs estimated with OLS, the impacts on the quantiles are also imprecisely estimated, so that the confidence bands are wide and the null of no impact cannot be rejected in a large majority of cases.

\subsubsection{Impacts on Labor Supply}

Next, in Table 5 we show the estimated ITTs for labor supply, separately for adults of age 16-75 (in the top panel A) and for teenagers (13-19, bottom panel B). For each individual of age 10 and above, the survey recorded the two most important activities the individual was involved in during the previous 12 months. For each activity, records were then taken about the number of weeks spent in such activity, the number of days usually spent per week as well as the number of hours spent per day. Hours were counted as 'work' if they were related to one of the following activities: crop cultivation, care of livestock, fishing, mining, manufacture and processing, retail and wholesale trade, finance, public administration, education, health, and social services or other services. Hours 
spent in school or in domestic work were listed separately.

When we look at adults, none of the estimates is significant at standard levels and all are small. In areas assigned to microcredit, the ITT is 1.1 hours per week, almost completely explained by an increase in time spent in self-employment activities. The standard errors are not small, however, so that substantively important impacts cannot be ruled out and the $95 \%$ confidence interval for total hours is -1.7 to 3.9 . The ITT for women's time spent in self-employment activities is -1.1 (standard error 1.04) suggesting that access to microcredit did not lead to substantive changes in women's time spent in economic activities. ${ }^{15}$

Moving now to teenagers, we find no evidence of substantive changes in the total number of hours spent working, with a point estimate of -0.7 . However, the estimated impacts on hours in self-employment activities is negative and large $(-1.7)$ relative to the endline mean in control areas (12.4) and for girls the magnitude is even larger (-2.6) and significant at the $10 \%$ level. For girls, the lower bound of the $95 \%$ confidence interval $(-5.6)$ is almost as large as the endline average in control areas (6.9). Time spent by teenagers in activities outside the household was on average limited (2.2 hours per week at endline in control areas) but the ITT is relatively large (1 hour per week) and the null of no impact is rejected at the $10 \%$ level.

\subsection{Impacts on Child Schooling and Other Socio-economic Indicators}

Next, in Panel A of table 7 we turn to the analysis of child schooling. Ex-ante, it is not clear that improvements in such indicator should have been expected, even if our results had shown (as they do not) clear evidence of improvements in income-generating activities. ${ }^{16}$ In fact, while income effects and reductions in credit constraints will ceteris paribus typically raise child schooling, the opposite effect may arise if access to credit increases sufficiently the returns to child labor (Wydick 1999). For instance, in the RCT described in Augsburg et al. (2012) the authors found that increased borrowing from microfinance was associated to an increase in labor supply and a decrease in schooling among teenagers in poorer families.

In Ethiopia, public primary and secondary schools are nominally free, although associated costs such as textbooks and uniforms must be born by the families, see Appendix A.1 for additional

\footnotetext{
${ }^{15}$ The low numbers of hours worked on average at endline in control areas are unconditional means that also include individuals who did not work, most of which were women. If we estimate this statistic using only individuals for whom work was the primary activity, the averages become 38 hours/week for men and 25 for women.

${ }^{16}$ Note that Table 6 is missing to keep table numbering consistent among the different microcredit evaluations in this Journal. In our study this table is skipped because do not have any information on household consumption.
} 
details. In rural areas it is common for children to start school late. At baseline, only $15 \%$ of 7-year old children were attending school, while the proportion increased monotonically to $54 \%$ at age 14 and declined afterwards. Such staggered start of school leads to the lack of clear jumps in enrollment at specific ages, and to a large variation in the age of children enrolled in the same grade. We thus analyze separately impacts for children 6 to 15 and for individuals 16-20. For each individual in the household roster, enumerators recorded years of school completion as well as school attendance at the time of the interview. Attendance was measured in a binary way, simply asking about whether the individual was 'currently attending school' while no information was collected on learning outcomes such as test scores. For individuals 10 or older, the questionnaire also included separate questions about time allocation, so we will also look at labor supply and domestic work among children 10-15.

In column 1, we see that the estimated program impact on schooling attendance of children 6-15 is positive but very small (0.025) and not significant. This compares to a very large increase in schooling attendance that took place in this age group in untreated areas, where the indicators increased from 37 to $55 \% .{ }^{17}$ The standard error is relatively large, however, so that a $95 \%$ confidence interval for the ITT ranges from a 6.5 percentage point decline to an 11.5 percentage points increase in attendance. When we look at time allocation among the subset of these children for whom such data were collected (that is, children of age 10-15) we find similarly small and not significant impacts in the number of hours worked, regardless of whether we look at outside or self-employment activities. Among girls in the same age range the proportion for whom domestic chores was the primary activity increased by 5 percentage points relative to control areas. This is a large figure relative to the level at endline in control areas (14\%) but is estimated imprecisely and is thus not significant. In column 5 we also show that we do not find any evidence of changes in schooling attendance among older cohorts (16 to 20).

Next, we look at indicators of women's empowerment. When a woman of age 15-49 was present in a male-headed household (about $90 \%$ of households were, see Table 1), surveyors asked the woman about who in the household was involved in decision-making related to 20 different topics, ranging from children's health and education, to contraceptive use, savings and the woman's involvement

\footnotetext{
${ }^{17}$ Such overall large increase in school attendance was broadly consistent with nationwide trends. For instance, data from the Ethiopia Demographic and Health Surveys show that between 2000 and 2005 the percentage of 10-14 year old with some primary education increased from 37 to $55 \%$ among girls and from 47 to $58 \%$ among boys, see Macro International Inc. (2007).
} 
in the labor market, see Appendix A.11 for details. We thus construct a measure of empowerment as the fraction of decisions where the woman stated she was involved, and a separate measure calculated taking into account only seven domains - such as savings decisions or labor market participation - that we categorized as being more clearly 'economic' in nature. Interviewers were instructed to complete the corresponding section of the questionnaire without the spouse being present during the interview, to enhance the truthfulness of the responses.

At follow-up, both indicators show that in control areas women were on average involved in about $80 \%$ of decisions, suggesting a high degree of participation in the study areas. The estimates in columns 1 and 2 of panel $\mathrm{B}$ show no evidence of impacts in either indicator. Both estimates are relatively small and actually negative ( -0.047 and -0.042 respectively) although neither is statistically significant at standard levels. For both indicators the $95 \%$ confidence intervals are wide although we can reject the null of positive ITTs larger than 3.5 percentage points. The lack of beneficial program for these indicators is perhaps not surprising given that, unlike what is often observed in many micro-finance institutions worldwide, ACSI/OCSSC did not lend exclusively or predominantly to women.

In column 3 of panel B we also find no significant impact on the resale value of a list of assets owned by households, including radios, electric stoves, kerosene/pressure lamps, beds, tables, chairs, bicycles, motorcycles/scooters, cars and trucks. The ITT is negative but close to zero ( -5 Birr) and the standard error (13) sufficiently small that we can reject the null of economically important impacts on this variable. However, the list of assets is clearly non-exhaustive, so these estimates are only a very coarse approximation of the impacts on household wealth.

In column 4 we see that microcredit had barely any impact on the fraction of households where at least one member was 'seriously ill' during the previous three years (that is, in the period of time between baseline and follow-up surveys). This is of course a very coarse health indicator, and in addition it was only measured at follow-up, so in this case we estimate the ITT with a version of model (1) in levels. ${ }^{18}$

Finally, in column 6 of panel B we see that microcredit was associated with a relative increase in the number of months of food insecurity. The estimate is large (0.5 months) and significant at the $5 \%$ level. Given the coarse way this variable was measured it is possible that this result is

\footnotetext{
${ }^{18}$ The estimates are similarly negative but close to zero and not significant if we look at the probability of a child under six being seriously ill in the previous three years, or at health expenditures for serious illness during the same period (results not reported).
} 
spurious, also because the results on economic activities, while mostly not significant, suggested if anything some improvements in areas with increased access to credit.

\section{Discussion and Conclusions}

In this paper we have evaluated the impact on several socio-economic outcomes of the introduction of microfinance in rural areas of Amhara and Oromiya (Ethiopia) in the context of a clustered randomized field trial carried out between 2003 and 2006. Our results should be a useful addition to a still limited number of RCTs that evaluate the impact of introducing microloans in communities who had previously no access to it. Our empirical framework is perhaps closer to that in Crépon et al. (2011), who describe an RCT conducted in Morocco: the study area was rural and with little access to credit at baseline, the interest rate charged by the micro-lenders was relatively low, loans were granted to both men and women and used mostly to fund crop production and livestock activities. In addition, in both these studies (and unlike, for instance, Banerjee et al. 2013) there was very little activity of other MFIs before or during the study, so that the estimates can be interpreted as impacts of 'first generation' microcredit, in areas where access to this form of credit was novel and largely limited to borrowing from the partner MFIs.

ACSI and OCSSC, the two MFIs involved in our evaluation, did not always comply with the experimental protocol so that actual and randomly assigned treatment coincide in only $78 \%$ of the 'peasant associations' (PAs) included in the study. Throughout the paper we thus focused on intent-to-treat estimates, interpreted as impacts of residing in a PA randomly assigned to see the introduction of micro-lending. Three years after the start of the trial we estimate that in areas where the two MFIs were assigned to start operating the fraction of households with loans was 25 percentage points higher than in areas assigned as controls. These were very large increases, especially relative to the pre-intervention borrowing rates of $13 \%$ throughout the study area. The average loan size among borrowers was large, close to $80 \%$ of the poverty line in Ethiopia in terms of adult consumption per year. We also do not find evidence that the micro-loans supplanted pre-existing sources of credit.

The magnitude of the increase in borrowing is large also when compared to other recent RCTs that evaluated impacts of microfinance in other locations. The intervention evaluated in Crépon et al. (2011) increased access to credit by 13 percentage points relative to control area, in Hyderabad (India) Banerjee et al. (2013) found that after about 1.5 years program areas saw 9 percentage points 
more borrowing from MFIs but also 5 percentage points less borrowing from informal sources, while credit usage increased by 12 percentage points in a Mexico-based RCT (Angelucci et al. 2014) and by 24 percentage points in Mongolia (Attanasio et al. 2013), although in this latter case the study population was composed of women who had expressed an interest in borrowing. Our respondents reported that a large majority of loans were used to fund production activities although, unlike in the most common narrative of microfinance, investment in non-farm small businesses played only a minor role, with most funds reported as being invested for crop cultivation and livestock-related activities.

Despite the remarkable increase in borrowing, we do not find clear evidence of widespread improvement in socio-economic indicators in treated areas, although most estimates are imprecise and most confidence intervals are so large that both substantial improvements and large declines in a number of indicators cannot be rejected by the data. Of a total of 40 outcomes, including input and output measures of income-generating activities, labor supply, child school attendance, indicators of women's empowerment and (coarse) indicators of health and food adequacy, only five are significant at standard levels (and none is at the 1\% level), and even these do not point univocally to a clear improvement in household welfare. The null of no impact can only be rejected for expenses for crop cultivation (at the 5\% level, with the point estimate indicating an increase), livestock sales (10\%, increase), hours of work for teens' activities outside of the households (10\%, increase), girls' hours of work in self-employed activities (10\%, decrease) and months of food insecurity (5\%, increase). But given the very large number of outcomes analyzed, mere chance may have produced such rejections of the null hypothesis of no impacts even if the null had been true for all of them. Had we used more conservative, Bonferroni-type tests to evaluate significance in individual equations, the null of no impact would not have been rejected in most cases, with the major exception of the estimated impacts on borrowing behavior. ${ }^{19}$ Note that the large increase in borrowing in treated areas indicates that the lack of significant changes in socio-economic outcomes was not a mere result of low demand for the loans. On the other hand, our results cannot distinguish between a scenario where the loans were not adapted to the needs of rural households versus an alternative one where the returns to investment were anyway low in these areas, although the high take up rates suggest that a large fraction of households valued the loans sufficiently to justify borrowing.

When we look at income-generating self-employment activities, we find that increased access

\footnotetext{
${ }^{19}$ For recent examples of program evaluations that take explicitly into account this multiple inference issue see for instance McKenzie et al. (2009) and Angelucci et al. (2014).
} 
to loans was not associated with more non-farm business creation, while we find some evidence of impacts on the scale of farm activities, although the estimates are imprecise. The intent-totreat for total revenues from self-employment activities is very large (712 Birr, about half of the poverty line expressed as total consumption per adult/year) but the $95 \%$ confidence interval is large enough to include both a $110 \%$ increase and a $15 \%$ decrease relative to control areas. Similarly, the confidence interval for the impact on net revenues from the same activities (513 Birr) includes both an $80 \%$ increase and a $40 \%$ decrease relative to control areas. Results from quantile regressions show that these impacts were driven by changes in the distributions above the median, although these estimates are equally imprecise. The number of hours worked by adults remained similar in treatment and control areas, and we also do not find impacts on time spent by teenagers in selfemployment. Changes in schooling attendance were also generally similar across experimental arms for both children 6-15 and for older 16-20 year-olds, although the corresponding confidence intervals once again include substantively large positive and negative figures. As in Crépon et al. (2011) and Banerjee et al. (2013), we find that increased access to loans was not associated with significant improvements in indicators of women's empowerment (our point estimates actually indicate a small but not statistically significant decline), but it should be recalled that in our study (as in Crépon et al. 2011) micro-lenders did not target exclusively women borrowers.

Finally, one of the few statistically significant results indicates a one-half month increase in the number of months of food insecurity in treatment relative to control areas (where the average was 1.3 months per year). Unfortunately this very coarse indicator was the only proxy of consumption in our data, so we cannot do much to probe whether this finding (which appears to be at odds with the noisy but generally positive estimates for income) was spurious. More generally, the lack of consumption data is a clear drawback in our analysis, because in this respect we cannot compare our findings with those of other evaluations that have found that access to microcredit, while leaving aggregate and non-durable consumption largely unchanged, increased consumption of durables while decreasing expenditures in 'temptation goods' such as cigarettes or alcoholic beverages.

One relative strength of our study is that the time interval between pre and post-intervention surveys was relatively long, approximately three years. This is potentially important, because the literature has highlighted that the need for lumpy investments may actually decrease certain welfare indicators in the short term, before investments have paid off (see for instance Banerjee et al. 2013 or Fulford 2011). On the other hand, and unlike Banerjee et al. (2013), we do not have data from 
the interim period between baseline and endline surveys, so we cannot gauge to what extent the immediate impacts differed from those observed at endline.

An additional shortcoming of our study is that, although households from the same villages were surveyed before and after treatment, it was not the same households that were surveyed. We thus have a panel of villages but not of households. Having baseline data is still useful because it allows us to gauge to what extent observed household characteristics were balanced across different experimental arms at baseline, and also allows us to control in the estimation for any time-invariant community-level confounder. However, the lack of baseline data limits severely our ability to estimate heterogeneous treatment effects. This is potentially very important, because the existence of heterogeneous impacts is a common theme among RCTs evaluating other microfinance programs. We are also unable to study attrition explicitly, although our data suggest overall that the composition of the population among experimental arms was not endogenously affected by the program.

A final but crucial cautionary note is that the failure to identify statistically significant impacts on key outcomes such as net revenues or livestock ownership may also have been the result of measurement error or insufficient statistical power. Recall that the data used in this paper come from a randomized controlled trial whose primary purpose was the evaluation of FPPs and microloans on contraceptive choices. The power calculations were thus conducted in relation to such fertility-related outcomes. Revenues and costs are notoriously difficult to measure in household surveys (de Mel et al. 2009) and measurement error of a non-binary dependent variable, while not causing estimation bias under certain conditions, will increase the standard errors of the estimates. The figures in Table 1 clearly show that standard deviations were large for outcomes expressed in monetary terms. For instance, mean revenues from non-farm business in control areas at baseline was 310 Birr with a standard deviation about 20 times as large, while the mean value of livestock was 1,502 Birr, with a standard deviation of 2,021 and a very high intra-PA correlation of about 0.20. For this latter outcome, the point estimate for the ITT in Table 3 show impacts of about 200 Birr, which correspond to a small effect size of about 0.1. Under such scenario, and taking into account a total of 60 households in each of 60 clusters, the probability of rejecting the null of no impact would be only $21 \%$ using a $10 \%$ significance level. ${ }^{20}$

While these important caveats need to be kept in mind, our results are overall consistent with the broad framework described in the survey by Banerjee (2013), with increased access to microfinance

\footnotetext{
${ }^{20}$ We calculated power using the Optimal Design software, version 1.56.
} 
associated with some improvements in living standards of beneficiary communities, but without compelling evidence of a true transformative power of microfinance. Our study thus provides additional power to the cautionary note sounded early on by Morduch (1999) in relation to the potential of microfinance as a development tool against poverty. 


\section{References}

Angelucci, M., D. Karlan, and J. Zinman (2014). Microcredit impacts: Evidence from a randomized microcredit program placement experiment by Compartamos Banco. Working Paper.

Armendariz de Aghion, B. and J. Morduch (2005). The Economics of Microfinance. Cambridge and London: MIT Press.

Attanasio, O., B. Augsburg, R. D. Haas, E. Fitzsimons, and H. Harmgart (2013). Group lending or individual lending? Evidence from a randomised field experiment in Mongolia. EBRD Working Paper No. 136.

Augsburg, B., R. De Haas, H. Harmgart, and C. Meghir (2012). Microfinance at the margin: Experimental evidence from Bosnia and Herzegovina. Working Paper.

Banerjee, A. (2013). Microcredit under the microscope: What have we learned in the past two decades, and what do we need to know? Annual Reviews of Economics 5, 487-519.

Banerjee, A., E. Duflo, R. Glennerster, and C. Kinnan (2013). The miracle of microfinance? Evidence from a randomized evaluation. MIT Department of Economics.

Brau, J. C. and G. M. Woller (2004). Microfinance: A comprehensive review of the existing literature. Journal of Entrepreneurial Finance and Busines Ventures 9(1), 1-26.

Buera, F. J., J. P. Kaboski, and Y. Shin (2013). The macroeconomics of microfinance. Working Paper.

Crépon, B., F. Devoto, E. Duflo, and W. Parienté (2011). Impact of microcredit in rural areas of Morocco: Evidence from a randomized evaluation. Working Paper.

de Mel, S., D. J. McKenzie, and C. Woodruff (2009). Measuring microenterprise profits: Must we ask how the sausage is made? Journal of Development Economics 88(1), 19-31.

Desai, J. and A. Tarozzi (2011). Microcredit, family planning programs and contraceptive behavior: Evidence from a field experiment in Ethiopia. Demography 48(2), 749-782.

Fulford, S. (2011). Financial access, precautions, and development: Theory and evidence from India. Working Paper, Department of Economics, Boston College, Boston MA.

Heckman, J., R. LaLonde, and J. Smith (1999). The economics and econometrics of active labor market programs. In O. Ashenfelter and D. Card (Eds.), Handbook of Labor Economics, Vol. 3A. Amsterdam, The Netherlands: Elsevier Science.

Imbens, G. W. and J. D. Angrist (1994). Identification and estimation of local average treatment effects. Econometrica 62(2), 467-475.

Kaboski, J. P. and R. M. Townsend (2012). The impact of credit on village economies. American Economic Journal: Applied Economics 4 (2), 98-133.

Karlan, D. and J. Zinman (2010). Expanding credit access: Using randomized supply decisions to estimate the impacts. Review of Financial Studies 23(1), 433-464.

Karlan, D. and J. Zinman (2011). Microcredit in theory and practice: Using randomized credit scoring for impact evaluation. Science 332(6035), 1278-1284.

Macro International Inc. (2007). Trends in demographic and reproductive health indicators in Ethiopia: Further analysis of the 2000 and 2005 Demographic and Health Surveys data. Technical report, Macro International Inc., Calverton, Maryland, USA.

McKenzie, D., J. Gibson, and S. Stillman (2009). The impacts of international migration on remaining household members: Omnibus results from a migration lottery program. Working Paper. 
Morduch, J. (1999). The microfinance promise. Journal of Economic Literature 37(4), 1569-1614.

Ofcansky, T. P. and L. Berry (1991). Ethiopia: A country study. Washington: GPO for the Library of Congress. http://countrystudies.us/ethiopia/90.htm.

Pronyk, P. M., J. R. Hargreaves, J. C. Kim, L. A. Morison, G. Phetla, C. Watts, J. Busza, and J. D. Porter (2006). Effect of a structural intervention for the prevention of intimate-partner violence and HIV in rural South Africa: a cluster randomised trial. The Lancet 368(9551), 1973-1983.

Wolday, A. (2002). Product development in Ethiopia microfinance industry: Challenges and prospects. In N. Zaid et al. (Ed.), Micro Finance Theory Policy and Experience. Proceedings of the International Workshop on the Dimension of Micro Finance Institutions in Sub Saharan Africa: Relevance of International Experience. Mekelle University.

World Bank (2008). Global purchasing power parities and real expenditures, 2005. Technical report, International Comparison Program, Washington DC: World Bank. Available at www.worldbank.org/data/icp.

Wydick, B. (1999). The effect of microenterprise lending on child schooling in guatemala. Economic Development and Cultural Change 47(4), 853-869. 
Figure 1: Study Areas

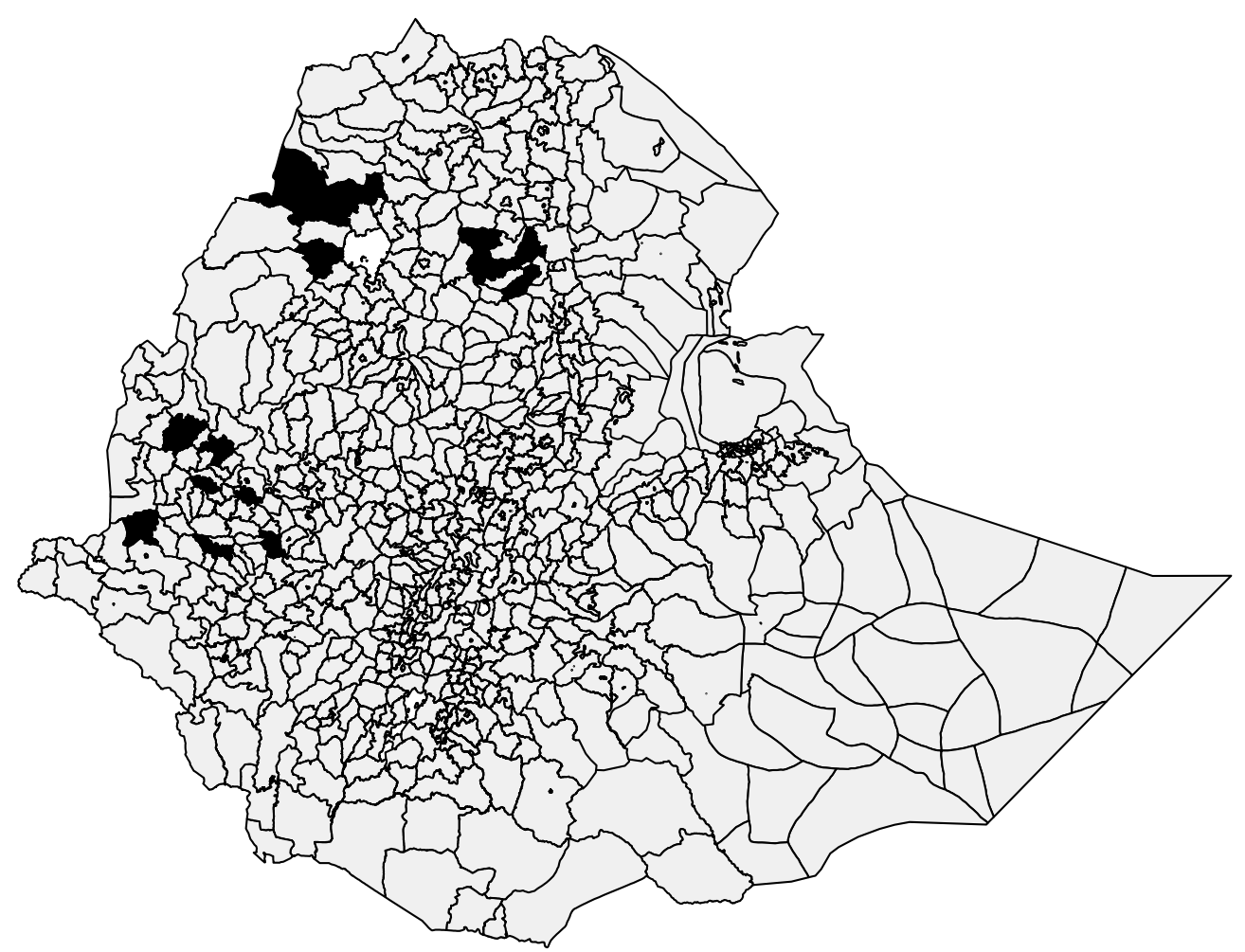

Source: Geo-spatial data from http://maps.worldbank.org/. Each contour represents an administrative unit called a woreda. The woredas where study PAs were located are shown in black. The northern-most woredas are those in Amhara and the southern-most ones are those in Oromiya. 
Figure 2: Results of Quantile Regressions

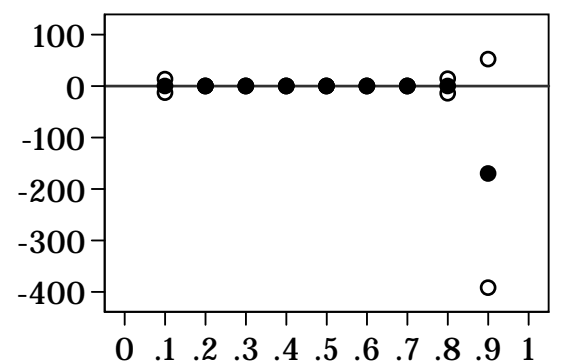

A. Non-farm business net sales

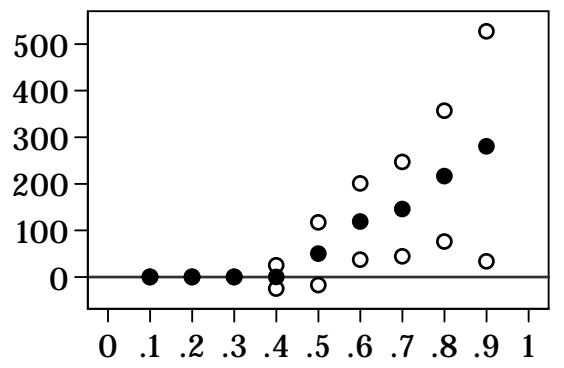

C. Crop costs

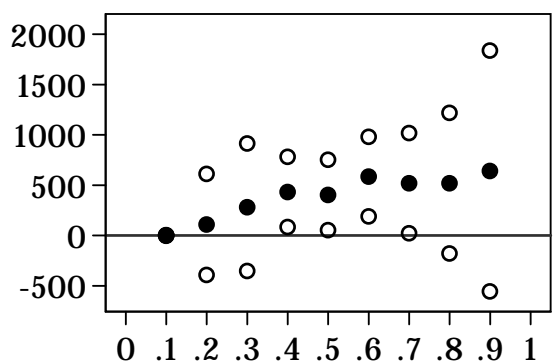

E. Total value of livestock

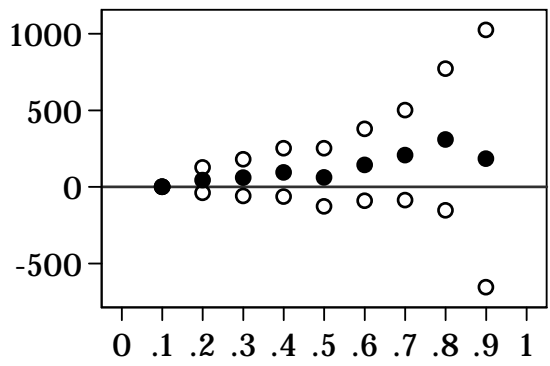

G. Total revenues from self-employment

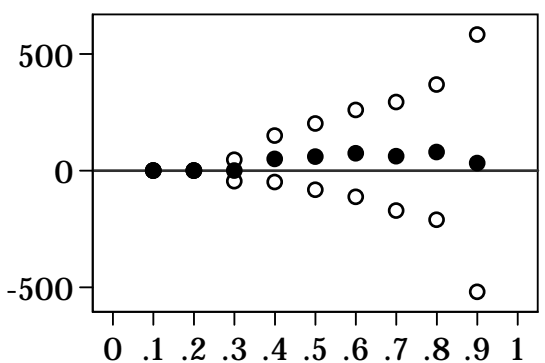

B. Net crop sales

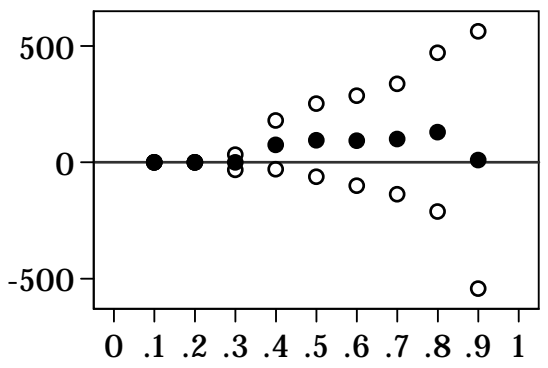

D. Crop sales

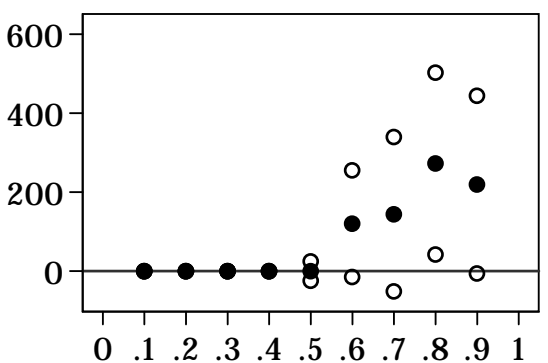

F. Livestock sales

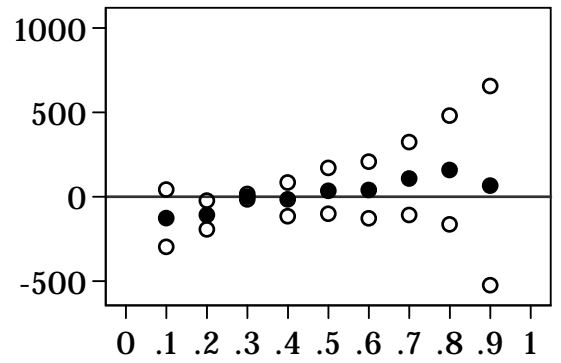

$\mathrm{H}$. Total net revenues from self-employment

Notes: Data from baseline (2003) and endline (2006) surveys. Each graph shows point estimates (black dots) and $90 \%$ confidence bands (delimited by the white dots) for the results of ten quantile regressions for the outcome indicated at the bottom left of each figure. In each quantile regression there are eight right-hand side variables, that is, the constant and the three arm-specific dummies $M F, F P$ and Both, interacted or not with the endline dummy Post. All estimates use sampling weights and the standard errors are estimated using 250 block-bootstrap replications using PAs as blocks. The quantile is indicated along the horizontal axis, while all estimates are measured in 2006 Birr. The PPP exchange rate according to the latest World Bank figures is 2.25 Birr/1USD (World Bank 2008). 
Table 1: Baseline Summary Statistics and Tests of Balance

\begin{tabular}{|c|c|c|c|c|}
\hline & \multirow{2}{*}{\multicolumn{2}{|c|}{$\begin{array}{c}\text { (1) } \\
\text { Control } \\
\text { (Assigned) }\end{array}$}} & \multirow{2}{*}{\multicolumn{2}{|c|}{$\begin{array}{c}\text { (3) } \\
\text { Assigned } \\
\text { Treatment - Control }\end{array}$}} \\
\hline & & & & \\
\hline & Mean & St. Dev. & Coeff. & $\mathrm{p}$-value \\
\hline \multicolumn{5}{|l|}{ Household composition } \\
\hline \# members & 5.22 & 2.14 & -0.046 & 0.750 \\
\hline$\#$ adults $(\geq 16$ years old $)$ & 2.43 & 1.01 & 0.040 & 0.522 \\
\hline \# children $(<16$ years old $)$ & 2.79 & 1.78 & -0.086 & 0.490 \\
\hline Male head & 0.873 & 0.333 & -0.003 & 0.857 \\
\hline Head age & 40.9 & 13 & -0.556 & 0.363 \\
\hline Head with no education & 0.734 & 0.442 & -0.019 & 0.697 \\
\hline \multicolumn{5}{|l|}{ Access to credit: } \\
\hline$\overline{\text { Loan from } \mathrm{RCA}}$ & 0.021 & 0.142 & -0.006 & 0.208 \\
\hline Loan from other MFI & 0.005 & 0.0737 & -0.002 & 0.547 \\
\hline Loan from a Banks and cooperatives & 0.026 & 0.16 & 0.000 & 0.951 \\
\hline Informal loan & 0.076 & 0.264 & -0.012 & 0.592 \\
\hline Any type of loan & 0.131 & 0.337 & -0.011 & 0.623 \\
\hline Any type of loans initiated by a woman & 0.017 & 0.13 & 0.001 & 0.882 \\
\hline \multicolumn{5}{|l|}{ Amount borrowed from (in 2006 Birr): } \\
\hline Loans from RCA & 11.0 & 94.8 & -3.260 & 0.377 \\
\hline Other MFI & 1.4 & 26.0 & -0.522 & 0.570 \\
\hline Banks and Cooperatives & 8.4 & 79.2 & 0.199 & 0.957 \\
\hline Informal loan & 14.9 & 79.2 & 1.210 & 0.801 \\
\hline Total & 36.6 & 149.0 & -0.488 & 0.951 \\
\hline Loans initiated by woman & 7.3 & 85.6 & -3.790 & 0.372 \\
\hline \multicolumn{5}{|l|}{ Income-generating activities } \\
\hline Agriculture is main economic activity of household & 0.855 & 0.352 & -0.0185 & 0.369 \\
\hline Total revenue from crop sales last 12 months & 203 & 650 & -38.3 & 0.485 \\
\hline Total expenditure for crops last 12 months & 89.9 & 977 & -10.3 & 0.715 \\
\hline \# of large animals owned & 2.84 & 5.37 & -0.374 & 0.117 \\
\hline Total value of livestock & 1502 & 2021 & -122 & 0.426 \\
\hline Total revenues from livestock sales last 12 months & 160 & 423 & 12.8 & 0.714 \\
\hline Total sales from non-farm self-employment last $12 \mathrm{~m}$. & 310 & 6804 & -147 & 0.318 \\
\hline Total costs for non-farm self-employment last $12 \mathrm{~m}$. & 17.2 & 144 & 6.51 & 0.497 \\
\hline \# of non-farm self-employment activities & 0.108 & 0.333 & 0.017 & 0.591 \\
\hline \# of non-farm self-empl. act. managed by women & 0.042 & 0.212 & 0.011 & 0.488 \\
\hline Transfers in cash or kind last 12 months & 115 & 443 & 28.2 & 0.454 \\
\hline Income from wages last 12 months & 174 & 1100 & -0.709 & 0.990 \\
\hline \multicolumn{5}{|l|}{ Other Indicators of Socio-Economic Status } \\
\hline$\overline{\text { Total value of selected assets } \dagger}$ & 36.9 & 62.7 & 3.57 & 0.564 \\
\hline Surface water as main source for drinking & 0.264 & 0.441 & 0.091 & $* 0.093$ \\
\hline Number of months of insufficient food in a typical year & 2.4 & 1.9 & -0.2 & 0.224 \\
\hline Distance to nearest health facility (minutes) & 89.7 & 90.6 & 11.5 & 0.507 \\
\hline Distance to nearest market (minutes) & 79.0 & 68.6 & 4.6 & 0.661 \\
\hline
\end{tabular}

Notes: Data from baseline (2003) survey. Sample size is $n=6,412$, of which 3, 216 assigned to treatment and 3, 196 assigned to Control. Columns 1 and 2 report statistics for households in PAs where ACSI/OCSSC were not randomly assigned to start lending. Column 3 shows the difference between the mean for households in areas assigned to ACSI/OCSSC and the means in column 1. Column 4 shows p-values for the test of equality of means, robust to intra-PA correlation. The number of clusters (PAs) is 133. Asterisks denote statistical significance at the $10\left(^{*}\right), 5(* *)$ or $1(* *) \%$ level. The joint null of equal means is rejected at standard levels $(F(34,99)=2.10$, p-value $=0.0025)$. When testing the joint null we exclude household size because of collinearity with the variables that describe the demographic household composition. All figures expressing monetary values have been converted into 2006 Birr using region-specific consumer price indexes (CPIs) constructed by the Central Statistical Agency of Ethiopia. In Amhara, the CPI increased from 114.6 in January-May 2003 to 158.1 in March-July 2006 (a 38\% increase), while in Oromiya the increase was from 122.8 to 156.8 (a $28 \%$ increase). The PPP exchange rate according to the latest World Bank figures is 2.25 Birr/1USD (World Bank 2008). † Estimated from the resale value of the following items owned by the household: radio, electric stove, lamps, beds, tables and chairs, bicycles, motorcycles, cars and trucks. 
Table 2: Impacts on Borrowing

\begin{tabular}{|c|c|c|c|c|c|c|c|c|}
\hline & (1) & (2) & (3) & (4) & (5) & (6) & (7) & (8) \\
\hline & $\begin{array}{l}\text { ACSI \& } \\
\text { OCSSC }\end{array}$ & NGOs & $\begin{array}{c}\text { Banks } \\
\& \\
\text { Coops }\end{array}$ & $\begin{array}{c}\text { Informal } \\
\text { Sources }\end{array}$ & $\begin{array}{c}\text { All } \\
\text { sources }\end{array}$ & $\begin{array}{c}\text { All } \\
\text { sources: } \\
\text { Women }\end{array}$ & $\begin{array}{r}M F=1 \\
\times(t=1)\end{array}$ & $\begin{array}{l}\text { ACSI \& } \\
\text { OCSSC } \\
\text { S }\end{array}$ \\
\hline Panel A. Credit access & \multicolumn{6}{|c|}{ Any loan from } & $\begin{array}{c}1 \text { st } \\
\text { Stage }\end{array}$ & $\begin{array}{c}\text { 2nd } \\
\text { Stage }\end{array}$ \\
\hline Microcredit $\times$ Post & $\begin{array}{c}0.252^{* * *} \\
(0.058)\end{array}$ & $\begin{array}{c}0.026 \\
(0.030)\end{array}$ & $\begin{array}{c}0.019 \\
(0.039)\end{array}$ & $\begin{array}{l}-0.006 \\
(0.022)\end{array}$ & $\begin{array}{c}0.252^{* * *} \\
(0.064)\end{array}$ & $\begin{array}{c}0.081^{* * *} \\
(0.025)\end{array}$ & $\begin{array}{c}0.753^{* * *} \\
(0.009)\end{array}$ & $\begin{array}{c}0.357^{* * *} \\
(0.093)\end{array}$ \\
\hline Observations & 12675 & 12675 & 12675 & 12675 & 12675 & 12675 & 12675 & 12675 \\
\hline Endline mean in control & 0.0597 & 0.0138 & 0.081 & 0.052 & 0.223 & 0.056 & & 0.0597 \\
\hline$\underline{\text { Panel B. Loan amounts }}$ & \multicolumn{8}{|c|}{ Loan amounts (in 2006 Birr) } \\
\hline Microcredit $\times$ Post & $\begin{array}{c}368^{* * *} \\
(84)\end{array}$ & $\begin{array}{c}21 \\
(29)\end{array}$ & $\begin{array}{l}-0.6 \\
(54)\end{array}$ & $\begin{array}{c}3.6 \\
(8.5)\end{array}$ & $\begin{array}{c}389^{* * *} \\
(90)\end{array}$ & $\begin{array}{c}134^{* * *} \\
(32)\end{array}$ & $\begin{array}{c}0.753^{* * *} \\
(0.009)\end{array}$ & $\begin{array}{c}458^{* * *} \\
(120)\end{array}$ \\
\hline Observations & 12675 & 12675 & 12675 & 12675 & 12675 & 12675 & 12675 & 12675 \\
\hline Endline mean in control & 61 & 14 & 102 & 18 & 200 & 38 & & 61 \\
\hline
\end{tabular}

Notes: Data from 2003 and 2006 surveys. Standard errors (in brackets) and tests are robust to intra-PA correlation (there are 133 clusters/PA). All regressions also include PA fixed effects. The coefficients in columns 1-6 are OLS estimates of $\beta_{M F}$ in model (1) in the text. The dependent variables in columns 1-6 of panel A are defined as follows: a dummy for whether the household had an outstanding loan from ACSI/OCSSC (column 1), or from NGOs (2), or from a bank or cooperative (3), or from informal sources such as money lenders or other individuals (4), or from any sources (5), or if a woman in the household had a loan from any source (6). The dependent variables in columns 1-6 of panel B are the amounts corresponding to the loans defined in the column headers. The coefficients in columns 7 and 8 are from the 2SLS estimation of model (1) with $M F$ and $F P$ defined in terms of PA-level actual treatment status, with the corresponding PA-level randomly assigned variables (interacted with Post $t_{t}$ ) used as instruments. In column 7 we show the first-stage coefficient for (actual) $M F$ status interacted with Post $t_{t}$, while column 8 shows the second stage estimates of $\beta_{M F}$ for the same dependent variable as in column 1. The endline means reported at the bottom of each panel are calculated for areas that were randomly assigned to receive neither microcredit nor family planning: that is, the means are conditional on $M F=F P=0, t=1$. All statistics are calculated using sampling weights. Asterisks denote statistical significance at the $10\left(^{*}\right), 5(* *)$ or $1\left({ }^{* *}\right) \%$ level. All figures expressing monetary values are in 2006 Birr. The PPP exchange rate according to the latest World Bank figures is 2.25 Birr/1USD (World Bank 2008). 
Table 3: Impacts on Self-employment Activities: Expenses and Revenues

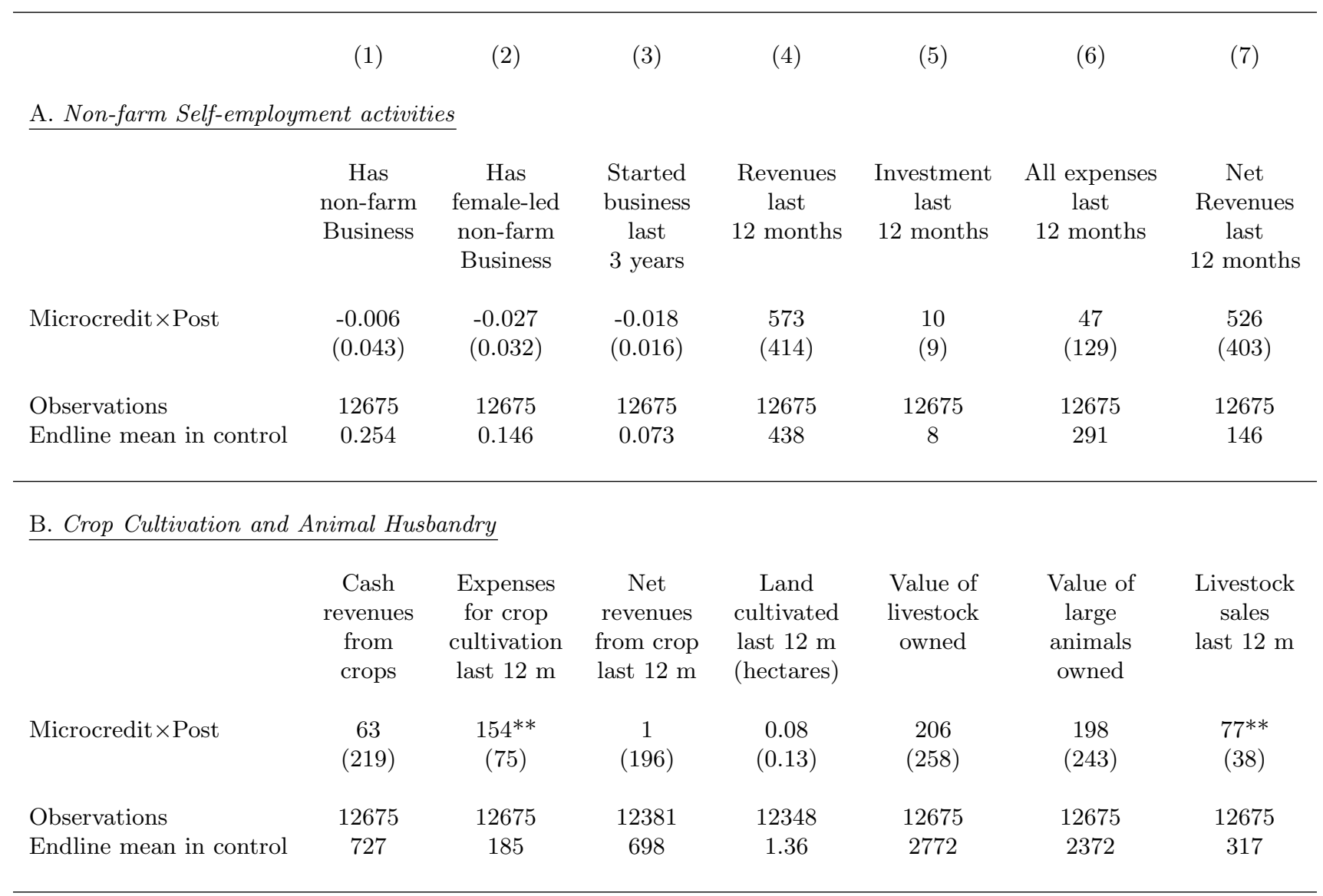

Notes: Data from 2003 and 2006 surveys. Standard errors (in parenthesis) are robust to intra-PA correlation. The rows labeled 'Microcredit $\times$ Post' display OLS estimates of $\beta_{M F}$ in model (1) in the text. All regressions use sampling weights. Asterisks denote statistical significance at the $10\left(^{*}\right), 5(* *)$ or $1\left(^{* *}\right) \%$ level. The control means at the bottom of each panel are calculated from endline data from areas where neither micro-credit nor FPP were introduced: that is, the means are conditional on $M F=F P=0, t=1$. Net revenues from crop cultivations are estimated as the difference between revenues and the fraction of costs imputed for the crop share sold by the household, see Appendix A.1 for details (this explains why net revenues from crops are not the simple difference between columns 1 and 2). All figures expressing monetary values are in 2006 Birr. The PPP exchange rate according to the latest World Bank figures is 2.25 Birr/1USD (World Bank 2008). In column 5 of panel A, 'investment' refers to expenditures in 'equipment, machinery, assets' for non-farm businesses. The figures in column 6 ('all expenses') add to such expenditures the amounts spent for hired labor, raw material, transport, storage and 'other items'. 
Table 4: Impacts on Income Indicators

\begin{tabular}{|c|c|c|c|c|c|c|}
\hline & (1) & $(2)$ & $(3)$ & $(4)$ & $(5)$ & $(6)$ \\
\hline & \multicolumn{6}{|c|}{ Household income last 12 months } \\
\hline & $\begin{array}{l}\text { Total } \\
\text { revenues } \\
\text { from self } \\
\text { employment } \\
\text { activities }\end{array}$ & $\begin{array}{c}\text { Total } \\
\text { costs } \\
\text { from self } \\
\text { employment } \\
\text { activities }\end{array}$ & $\begin{array}{l}\text { Total net } \\
\text { revenues } \\
\text { from self } \\
\text { employment } \\
\text { activities }\end{array}$ & Wages & Transfers & $\begin{array}{l}\text { Other } \\
\text { Income }\end{array}$ \\
\hline Microcredit $\times$ Post & $\begin{array}{c}712 \\
(479)\end{array}$ & $\begin{array}{c}199 \\
(156)\end{array}$ & $\begin{array}{c}513 \\
(431)\end{array}$ & $\begin{array}{c}49 \\
(84)\end{array}$ & $\begin{array}{l}-11 \\
(17)\end{array}$ & $\begin{array}{c}28 \\
(19)\end{array}$ \\
\hline Observations & 12675 & 12675 & 12675 & 12675 & 12675 & 12675 \\
\hline Endline Means in Control & 1482 & 727 & 755 & 294 & 23 & 31 \\
\hline
\end{tabular}

Notes: Data from 2003 and 2006 surveys. Standard errors (in parenthesis) are robust to intra-PA correlation. The rows labeled 'Microcredit $\times$ Post' display OLS estimates of $\beta_{M F}$ in model (1) in the text. All regressions use sampling weights. Asterisks denote statistical significance at the $10\left(^{*}\right), 5(* *)$ or $1\left(^{* *}\right) \%$ level. The control means at the bottom of each panel are calculated from endline data from areas where neither micro-credit nor FPP were introduced: that is, the means are conditional on $M F=F P=0, t=1$. Revenues (column 1) is the sum of revenues from sales of crop or livestock and products from non-farm businesses. Costs (column 2) is the sum of all costs for crop cultivation or non-farm businesses plus costs for animals purchased. Net revenues (column 3) is the difference between the two. See Appendix A.1 for additional details. All figures expressing monetary values are in 2006 Birr. The PPP exchange rate according to the latest World Bank figures is 2.25 Birr/1USD (World Bank 2008). 
Table 5: Impacts on Labor Supply

$(1)$
(3)

Panel A: Hours work / week: members 16-75 years old
$(4)$

\begin{tabular}{|c|c|c|c|c|c|}
\hline & $\begin{array}{l}\text { All adults } \\
\text { All } \\
\text { Activities }\end{array}$ & $\begin{array}{l}\text { All adults } \\
\text { Self } \\
\text { employment }\end{array}$ & $\begin{array}{l}\text { All adults } \\
\text { Outside } \\
\text { employment }\end{array}$ & $\begin{array}{c}\text { Women } \\
\text { Self } \\
\text { employment }\end{array}$ & $\begin{array}{c}\text { Women } \\
\text { Outside } \\
\text { employment }\end{array}$ \\
\hline Microcredit $\times$ Post & $\begin{array}{c}1.1 \\
(1.43)\end{array}$ & $\begin{array}{c}0.9 \\
(1.17)\end{array}$ & $\begin{array}{c}0.1 \\
(0.68)\end{array}$ & $\begin{array}{c}-1.1 \\
(1.04)\end{array}$ & $\begin{array}{c}1.0 \\
(1.03)\end{array}$ \\
\hline $\begin{array}{l}\text { Observations } \\
\text { Endline Means in Control }\end{array}$ & $\begin{array}{c}31769 \\
22.9\end{array}$ & $\begin{array}{c}31769 \\
18.1\end{array}$ & $\begin{array}{c}31769 \\
4.7\end{array}$ & $\begin{array}{c}16051 \\
8.8\end{array}$ & $\begin{array}{c}16051 \\
3.9\end{array}$ \\
\hline \multicolumn{6}{|c|}{ Panel B: Hours work / week: teens 13-19 years old } \\
\hline & $\begin{array}{l}\text { All teens } \\
\text { All } \\
\text { Activities }\end{array}$ & $\begin{array}{l}\text { All teens } \\
\text { Self } \\
\text { employment }\end{array}$ & $\begin{array}{l}\text { All teens } \\
\text { Outside } \\
\text { employment }\end{array}$ & $\begin{array}{c}\text { Girls } \\
\text { Self } \\
\text { employment }\end{array}$ & $\begin{array}{c}\text { Girls } \\
\text { Outside } \\
\text { employment }\end{array}$ \\
\hline Microcredit $\times$ Post & $\begin{array}{c}-0.7 \\
(1.42)\end{array}$ & $\begin{array}{l}-1.7 \\
(1.53)\end{array}$ & $\begin{array}{l}1.0^{*} \\
(0.54)\end{array}$ & $\begin{array}{l}-2.6^{*} \\
(1.52)\end{array}$ & $\begin{array}{c}0.5 \\
(0.66)\end{array}$ \\
\hline Observations & 10537 & 10537 & 10537 & 5372 & 5372 \\
\hline Endline Means in Control & 14.6 & 12.4 & 2.2 & 6.9 & 2.3 \\
\hline
\end{tabular}

Notes: Data from 2003 and 2006 surveys. Standard errors (in parenthesis) are robust to intra-PA correlation. The rows labeled 'Microcredit $\times$ Post' display OLS estimates of $\beta_{M F}$ in model (1) in the text. All regressions use sampling weights. Asterisks denote statistical significance at the $10\left(^{*}\right), 5(* *)$ or $1\left(^{* *}\right) \%$ level. The control means at the bottom of each panel are calculated from endline data from areas where neither micro-credit nor FPP were introduced: that is, the means are conditional on $M F=F P=0, t=1$. Hours of work are estimated from recall data about time allocation in the previous 12 months, see Appendix A.1 for details. 
Table 7: Impacts on Child Schooling and Other Socio-economic Indicators

\begin{tabular}{|c|c|c|c|c|c|}
\hline & $(1)$ & $(2)$ & $(3)$ & $(4)$ & $(5)$ \\
\hline \multicolumn{6}{|c|}{ Panel A: School attendance and time allocation of children } \\
\hline & \multirow{2}{*}{$\begin{array}{c}\% \text { of } \\
\text { children } \\
6-15 \text { in } \\
\text { school }\end{array}$} & \multicolumn{2}{|c|}{$\begin{array}{c}\text { Average hours/week worked } \\
\text { by children } 10-15\end{array}$} & \multirow{2}{*}{$\begin{array}{l}\% \text { of } 10-15 \\
\text { girls for whom } \\
\text { housework is } \\
\text { primary activity }\end{array}$} & \multirow{2}{*}{$\begin{array}{c}\% \text { of } \\
16-20 \\
\text { in } \\
\text { school }\end{array}$} \\
\hline & & $\begin{array}{c}\text { Self } \\
\text { employment }\end{array}$ & $\begin{array}{l}\text { Outside } \\
\text { activities }\end{array}$ & & \\
\hline Microcredit $\times$ Post & $\begin{array}{c}0.025 \\
(0.046)\end{array}$ & $\begin{array}{c}-0.6 \\
(1.71)\end{array}$ & $\begin{array}{c}0.0 \\
(0.59)\end{array}$ & $\begin{array}{c}0.047 \\
(0.038)\end{array}$ & $\begin{array}{c}0.009 \\
(0.034)\end{array}$ \\
\hline Observations & 22071 & 11774 & 11774 & 5924 & 7234 \\
\hline Endline mean in Control & 0.554 & 12.7 & 2.2 & 0.138 & 0.455 \\
\hline \multicolumn{6}{|l|}{ Panel B: Other indicators } \\
\hline & \multicolumn{2}{|c|}{$\begin{array}{c}\text { Empowerment: } \\
\% \text { decisions with } \\
\text { woman's involvement }\end{array}$} & \multirow[t]{2}{*}{$\begin{array}{l}\text { Value of } \\
\text { selected } \\
\text { assets }\end{array}$} & \multirow[t]{2}{*}{$\begin{array}{l}\text { Someone } \\
\text { seriously ill } \\
\text { last } 3 \text { years }\end{array}$} & \multirow[t]{2}{*}{$\begin{array}{l}\text { \# Months } \\
\text { of food } \\
\text { insecurity }\end{array}$} \\
\hline & All & Economic & & & \\
\hline Microcredit $\times$ Post & $\begin{array}{l}-0.047 \\
(0.037)\end{array}$ & $\begin{array}{l}-0.042 \\
(0.039)\end{array}$ & $\begin{array}{l}-5 \\
(13)\end{array}$ & $\begin{array}{l}-0.015 \\
(0.034)\end{array}$ & $\begin{array}{c}0.52^{* *} \\
(0.26)\end{array}$ \\
\hline Observations & 10500 & 10497 & 12675 & 6263 & 12675 \\
\hline Endline mean in Control & 0.816 & 0.790 & 73 & 0.47 & 1.29 \\
\hline
\end{tabular}

Notes: Data from 2003 and 2006 surveys. Standard errors (in parenthesis) are robust to intra-PA correlation. The rows labeled 'Microcredit $\times$ Post' display OLS estimates of $\beta_{M F}$ in model (1) in the text, except in column 4, Panel $\mathrm{B}$, because the dependent variable was measured only at follow-up (in this case we exclude the PA-specific fixed effects and the Post dummy and we include a region fixed effect). All regressions use sampling weights. The unit of observation is a child in all regressions of panel A, a woman in columns 1 and 2 of Panel B, and a household in columns 3 to 5 of Panel B. Asterisks denote statistical significance at the $10(*), 5(* *)$ or $1(* * *) \%$ level. The control means at the bottom of each panel are calculated from endline data from areas where neither micro-credit nor FPP were introduced: that is, the means are conditional on $M F=F P=0, t=1$. 


\section{A Appendix}

\section{A.1 Detailed Description of Outcomes}

Outstanding Loans: A household is labeled as having an outstanding loan if any household member owes money or goods to anyone at the time of the interview. Women's borrowing is identified by specific questions about the individual who contracted the loan.

Revenues and Costs from Non-farm Self-employment: The respondent was directed to include under this label "non agricultural enterprise which produces goods or services (for example, artisan, metalworking, tailoring, repair work; also include processing and selling your outputs from your own crops if done regularly)", shops or trading business. Respondents were also asked to report for how many days/weeks/months the business operated in the previous 12 months, and the total revenues from sales per unit of time. Total monetary costs incurred during the previous 12 months were also recorded separately for hired labor, raw materials, equipment/machinery, transport/packing/storage and other items. As an example, suppose that a business operated for 3 months, with weekly earnings of $100 \mathrm{Birr} /$ week, and with total costs of 500 Birr. Then we estimate 'net revenues' to be equal to $700 \operatorname{Birr}(=100 \times 4 \times 3-500)$. Separate information was collected for each existing business separately. The survey did not collect information on family labor or self-consumption of goods produced by the business.

Animal Husbandry: The value of animals owned is derived from questions about the expected revenues from their hypothetical sale at the time of the interview. The value of sales (in Birr) is the total revenue from actual sales of animals over the previous year. Separate information was collected for each animal type separately (types included cows, oxen, calves, bulls, camels, horses, donkeys, mules, sheep, goats, chicken and 'others'). No information was collected about costs for hired labor, veterinarian services, feed, etc. so for this economic activity we cannot calculate a value for 'net sales'.

Revenues and Costs from Crop Cultivation: Information was collected separately for each crop type (the principal crops were wheat, barley, teff, maize, sorghum/millet, beans and -in Oromiya - coffee. For each crop, the questionnaire recorded the total revenues from sales (in Birr) over the last 12 months, the share of the total crop sold, and the total amount of expenses incurred for cultivation and sales. We calculate net revenues from sales as the difference between revenues and the corresponding imputed costs, estimated as total costs multiplied by the fraction of the crop sold. So, for instance, if a household incurred a total cost of 500 Birr for cultivation and sold $50 \%$ of the quantity produced for a total of 300 Birr, net crop sales are calculated as $300-0.50 \times 500=50$ Birr.

Other Sources of Income: Income from wages is reported as total earnings (in Birr) in monetary or in-kind terms, for work conducted for someone else over the previous 12 months. Income from transfers include transfers in cash or kind received from relatives or friends. Other income includes any inflow in cash or kind from pensions, interests, rents, gambling, inheritances etc.

Hours of Work: For each individual of age 10 and above, the survey recorded the two most important activities the individual was involved in during the past 12 months. For each activity, records were then taken about the number of weeks spent in such activity, the number of days usually spent per week as well as the number of hours spent per day. Hours were counted as 'work' 
if they were related to one of the following activities: crop cultivation, care of livestock, fishing, mining, manufacture and processing, retail and wholesale trade, finance, public administration, education, health, and social services or other services. Hours spent in school or in domestic work were listed separately.

\section{A.2 Schooling in Ethiopia}

Primary school covers grades 1 to 8 , and by the end of eighth grade pupils must pass a national examination before they are allowed to start secondary school (grades 9 and 10). Students that pass another national examination at the end of the 10th grade are allowed to enroll in two years of 'preparatory' school (grades 11 and 12) and those who also pass a 12th grade exam are eligible to enroll in public universities. ${ }^{21}$

\section{A.3 Indicators of Women's Empowerment}

When a woman of age 15-49 was present in a male-headed household (almost $90 \%$ of households were male-headed, see Table 1), interviewers asked the woman to list all members involved in decisionmaking related to 20 different issues. Such issues included the following: 1. Food eaten at home; 2. Routine purchases for household items such as cleaning supplies; 3. The woman's own clothes; 4. The clothes of the woman's spouse; 5. Children's clothes; 6 . Children's education (to attend, and then continue); 7. The woman's health; 8. The health of the spouse; 9. Children's health; 10. Large expensive purchases for the household; 11. Giving money to the woman's parents/family; 12. Giving money to the spouse's parents/family; 13. Gifts for special occasions; 14. Monthly savings; 15. Sale of cattle; 16. Time the woman spends socializing; 17 . Whether the woman works outside the household; 18. Number of children to have; 19. Contraceptive use; 20. When daughters can marry.

We construct two indicators of empowerment. The first is the fraction of domains for which the woman is included as one of the decision-makers, while the second is calculated in the same way but including only domains with a more distinctly 'economic' content, which we roughly identify to be items 10-15 and 17 in the list above. In several instances a specific decision was not relevant for the household, in which case the decision was not considered in calculating the indicator. For instance, in a family with no children nor cattle, items 5, 6, 9, 15 and 20 would not be relevant, so the indicator would be calculated as the fraction out of 15 decisions where the woman was involved as a decision-maker.

\footnotetext{
${ }^{21}$ See Section $\mathrm{P}$ of the 2008 Statistical Abstract of Ethiopia, http://www.csa.gov.et/surveys/ Nationalstatistics/nationalstatistics2008/SectionP-Education.pdf.
} 


\section{A.4 Predictors of Actual Treatment Status}

Dependent Variable: Microcredit $=1$

Randomly assigned to microcredit

\# adults in households

\# children in households

Household head is male

Age of household head

Household head has no formal education

Household has loans from banks/cooperatives

Household has loans from informal lenders

At least one loan initiated by a woman

Agriculture is main economic activity of household

Total revenue from crop sales last 12 months

Total expenditure for crops last 12 months

\# of large animals owned

Total value of livestock

Total revenues from livestock sales last 12 months

Total sales from non-farm self-employment last $12 \mathrm{~m}$.

Total costs for non-farm self-employment last $12 \mathrm{~m}$.

\# of non-farm self-employment activities

\# of non-farm self-employment activities

Transfers in cash or kind last 12 months

Income from wages last 12 months

Total value of selected assets

Surface water as main source for drinking

\# of months of insufficient food

Distance to nearest market (minutes)

Constant

Observations

R-squared

P-value, $H_{0}$ : all slopes equal to zero
Coefficient s.e.

$0.647 \quad 0.070^{* * *}$

$0.009 \quad 0.012$

$0.004 \quad 0.005$

$\begin{array}{ll}-0.001 & 0.022\end{array}$

$\begin{array}{ll}-0.001 & 0.001\end{array}$

$-0.025 \quad 0.031$

$0.010 \quad 0.042$

$-0.165 \quad 0.046^{* * *}$

$-0.056 \quad 0.045$

$-0.046 \quad 0.028^{*}$

$\begin{array}{ll}0.002 & 0.001\end{array}$

$\begin{array}{ll}0.000 & 0.001\end{array}$

$0.003 \quad 0.002^{*}$

$\begin{array}{ll}0.001 & 0.001\end{array}$

$\begin{array}{ll}-0.001 & 0.001\end{array}$

$\begin{array}{ll}0.000 & 0.000\end{array}$

$\begin{array}{ll}0.002 & 0.002\end{array}$

$\begin{array}{cc}-0.041 & 0.041\end{array}$

$\begin{array}{ll}0.027 & 0.034\end{array}$

$\begin{array}{ll}-0.004 & 0.002^{* * *}\end{array}$

$-0.002 \quad 0.001^{* *}$

$\begin{array}{ll}0.002 & 0.004\end{array}$

$\begin{array}{ll}-0.037 & 0.032\end{array}$

$\begin{array}{ll}-0.008 & 0.007\end{array}$

$\begin{array}{ll}0.001 & 0.000\end{array}$

$0.268 \quad 0.072^{* * *}$

6410

0.46

Notes: Data from baseline (2003) survey. The figures are regression coefficients from an OLS regression of a dummy for actual treatment status (whether ACSI/OCSSC actually started operating in the PA) on a dummy for the randomly assigned treatment status (whether they were randomly assigned to start operating in the PA) and a series of predictors. Standard errors (in brackets) and tests are robust to intra-PA correlation. All statistics are calculated using sampling weights. Asterisks denote statistical significance at the $10\left(^{*}\right), 5(* *)$ or $1\left(^{* * *}\right) \%$ level. All figures expressing monetary values are quartic roots of values in 2006 Birr. 


\section{A.5 Changes in Sample Composition}

\begin{tabular}{cccccc}
$(1)$ & $(2)$ & $(3)$ & $(4)$ & $(5)$ & $(6)$ \\
& Means at follow-up & $\begin{array}{c}\text { Test of } \\
\text { equality } \\
\text { (p-value) }\end{array}$ & $\begin{array}{c}\text { Sample } \\
\text { Bize }\end{array}$ \\
\hline
\end{tabular}

\section{Panel A: Randomly assigned treatment}

Lived in current village of residence $<4$ years

\# Adults (16 or above)

Age of household head

Household head is male

Household head has no formal schooling

Household head $\geq$ primary schooling$$
0.032
$$

2.6

0.023

0.041

0.038

0.5463

12674

40.9

2.7

2.5

2.7

0.3818

12675

0.871

41.5

41.2

42.4

0.5866

12647

0.663

0.887

0.856

0.875

0.7275

12647

0.075

0.069

0.703

0.597

0.8788

12647

12647

\section{Panel B: Actual treatment}

Lived in current village of residence $<4$ years

\# Adults (16 or above)

Age of household head

Household head is male

Household head has no formal schooling

Household head has no formal schooling

0.022

2.6

0.025

0.065

0.036

0.5536

12674

41.2

2.7

2.4

2.6

$0.0500^{* *}$

12675

0.880

0.889

40.0

42.5

0.5693

12647

0.687

0.585

0.847

0.863

0.7103

12647

0.059

0.091

0.708

0.649

0.6881

12647

0.085

0.067

0.8394

12647

Notes: Data from baseline (2003) and endline (2006) surveys. The figures in columns 1-4 are means of the variables calculated for each treatment arm, defined according to the random assignment (Panel A) or according to actual implementation (Panel B). The figures in column 5 are p-values for the test of equal changes between baseline and endline across the four arms. The tests are performed by estimating OLS regressions of each household-specific outcome on PA-fixed effects, a dummy equal to one for endline observations, and this same dummy interacted with three treatment-specific dummies equal to one if the household lived in a PA where assigned (Panel A) or actual (Panel B) intervention was as indicated in columns 1-3. The test is robust to intra-PA correlation of residuals. All statistics are calculated using sampling weights. Asterisks denote statistical significance at the $10\left(^{*}\right)$, 5(**) or $1(* * *) \%$ level. 


\section{A.6 Impacts on Borrowing, Complete Results and Alternative Specifications}

(1)

$(2)$

(3)

$(4)$

$(5)$

(6)

Panel A. Credit access: Any loan from

\begin{tabular}{|c|c|c|c|c|c|c|}
\hline & $\begin{array}{l}\text { ACSI \& } \\
\text { OCSSC }\end{array}$ & NGOs & $\begin{array}{c}\text { Banks \& } \\
\text { Cooperatives }\end{array}$ & $\begin{array}{l}\text { Informal } \\
\text { Sources }\end{array}$ & All sources & $\begin{array}{l}\text { All sources } \\
\text { Women }\end{array}$ \\
\hline & \multicolumn{6}{|c|}{ OLS - Base estimates } \\
\hline Microcredit & $\begin{array}{c}0.252^{* * *} \\
(0.058)\end{array}$ & $\begin{array}{c}0.026 \\
(0.030)\end{array}$ & $\begin{array}{c}0.019 \\
(0.039)\end{array}$ & $\begin{array}{l}-0.006 \\
(0.022)\end{array}$ & $\begin{array}{c}0.252^{* * *} \\
(0.064)\end{array}$ & $\begin{array}{c}0.081^{* * *} \\
(0.025)\end{array}$ \\
\hline Family Planning (no microloans) & $\begin{array}{c}0.025 \\
(0.030)\end{array}$ & $\begin{array}{c}0.006 \\
(0.017)\end{array}$ & $\begin{array}{c}0.003 \\
(0.032)\end{array}$ & $\begin{array}{c}0.022 \\
(0.024)\end{array}$ & $\begin{array}{c}0.048 \\
(0.059)\end{array}$ & $\begin{array}{c}0.019 \\
(0.018)\end{array}$ \\
\hline Treated $\times$ Family Planning & $\begin{array}{l}-0.079 \\
(0.076)\end{array}$ & $\begin{array}{l}-0.028 \\
(0.029)\end{array}$ & $\begin{array}{l}-0.016 \\
(0.036)\end{array}$ & $\begin{array}{l}0.033 \\
(0.022) \\
\mathrm{LS}\end{array}$ & $\begin{array}{l}-0.058 \\
(0.064)\end{array}$ & $\begin{array}{c}0.010 \\
(0.031)\end{array}$ \\
\hline Microcredit & $\begin{array}{c}0.357^{* * *} \\
(0.093)\end{array}$ & $\begin{array}{c}0.042 \\
(0.051)\end{array}$ & $\begin{array}{l}0.030 \\
(0.060) \\
\text { OLS - No }\end{array}$ & $\begin{array}{c}-0.015 \\
(0.034) \\
\text { FP contro }\end{array}$ & $\begin{array}{c}0.353^{* * *} \\
(0.098)\end{array}$ & $\begin{array}{l}0.105^{* *} \\
(0.035)\end{array}$ \\
\hline Microcredit & $\begin{array}{c}0.189^{* * *} \\
(0.039)\end{array}$ & $\begin{array}{l}0.006 \\
(0.016)\end{array}$ & $\begin{array}{c}0.010 \\
(0.022)\end{array}$ & $\begin{array}{c}-0.014 \\
(0.010)\end{array}$ & $\begin{array}{c}0.182^{* * *} \\
(0.037)\end{array}$ & $\begin{array}{c}0.075^{* * *} \\
(0.017)\end{array}$ \\
\hline Microcredit & $\begin{array}{c}0.252^{* * *} \\
(0.058)\end{array}$ & $\begin{array}{c}0.026 \\
(0.031)\end{array}$ & $\begin{array}{c}\text { OLS - Villag } \\
0.019 \\
(0.040)\end{array}$ & $\begin{array}{c}\text { Fixed Eff } \\
-0.007 \\
(0.022)\end{array}$ & $\begin{array}{c}0.251^{* * *} \\
(0.064)\end{array}$ & $\begin{array}{c}0.081^{* * *} \\
(0.025)\end{array}$ \\
\hline
\end{tabular}

Panel B. Loan amounts (in 2006 Birr)

\begin{tabular}{|c|c|c|c|c|c|c|}
\hline & $\begin{array}{l}\text { ACSI \& } \\
\text { OCSSC }\end{array}$ & NGOs & $\begin{array}{c}\text { Banks \& } \\
\text { Cooperatives }\end{array}$ & $\begin{array}{c}\text { Informal } \\
\text { Sources }\end{array}$ & All sources & $\begin{array}{c}\text { All sources } \\
\text { Women }\end{array}$ \\
\hline & \multicolumn{6}{|c|}{ OLS - Base estimates } \\
\hline \multirow[t]{2}{*}{ Microcredit } & $368^{* * *}$ & 21 & -1 & 4 & $389^{* * *}$ & $134^{* * *}$ \\
\hline & $(84)$ & (29) & $(54)$ & (8) & $(90)$ & $(32)$ \\
\hline \multirow[t]{2}{*}{ Family Planning (no microloans) } & 42 & -1 & -39 & 14 & 14 & 11 \\
\hline & (31) & (13) & (47) & (10) & (57) & (15) \\
\hline \multirow[t]{2}{*}{ Microcredit $\times$ Family Planning } & 116 & $\begin{array}{l}-31 \\
-(98)\end{array}$ & 156 & 2 & 250 & 163 \\
\hline & \multicolumn{6}{|c|}{ 2SLS } \\
\hline \multirow[t]{2}{*}{ Microcredit } & $\begin{array}{c}460^{* * *} \\
(120)\end{array}$ & $\begin{array}{c}37 \\
(48)\end{array}$ & $\begin{array}{c}-46 \\
(105)\end{array}$ & $\begin{array}{c}5 \\
(13)\end{array}$ & $\begin{array}{c}447^{* * *} \\
(162)\end{array}$ & $\begin{array}{l}134^{*} \\
(77)\end{array}$ \\
\hline & \multicolumn{6}{|c|}{ OLS - No FP controls } \\
\hline \multirow[t]{2}{*}{ Microcredit } & $\begin{array}{c}392^{* * *} \\
(112)\end{array}$ & $\begin{array}{c}5 \\
(16)\end{array}$ & $\begin{array}{c}99 \\
(100)\end{array}$ & $\begin{array}{l}-2 \\
(6)\end{array}$ & $\begin{array}{l}497^{* *} \\
(199)\end{array}$ & $\begin{array}{c}203^{* *} \\
(82)\end{array}$ \\
\hline & \multicolumn{6}{|c|}{ OLS - Village Fixed Effects } \\
\hline Treated & $\begin{array}{c}367^{* * *} \\
(84)\end{array}$ & $\begin{array}{c}21 \\
(29)\end{array}$ & $\begin{array}{c}2 \\
(53)\end{array}$ & $\begin{array}{c}3 \\
(9)\end{array}$ & $\begin{array}{c}390^{* * *} \\
(90)\end{array}$ & $\begin{array}{c}135^{* * *} \\
(32)\end{array}$ \\
\hline
\end{tabular}

Notes: Data from 2003 and 2006 surveys. Standard errors (in parenthesis) are robust to intra-PA correlation. The dependent variables are defined as in Table 2. The base estimates corresponding to model (1) in the text are those labeled "OLS - Base estimates". For these results, the estimates in the row labeled 'Microcredit' are identical to those in Table 2, while those in the rows below show the results for $\hat{\beta}_{F P}$ and $\hat{\beta}_{B o t h}$. The results labeled "2SLS" are obtained estimating model (1) replacing assigned treatment with actual treatment and using the former indicators as instruments for the latter. The estimates labeled "OLS - No FP controls" are obtained ignoring the presence of Family Planning Programs, that is, imposing $\beta_{F P}=\beta_{B o t h}=0$ in model (1), with PA fixed effects. The results labeled "OLS - Village Fixed Effects" are obtained estimating the same model as in the base estimates but including village fixed effects instead of PA fixed effects. Asterisks denote statistical significance at the $10\left(^{*}\right), 5\left(^{* *}\right)$ or $1\left(^{* * *}\right) \%$ level. 


\section{A.7 Predictors of Borrowing}

Household head is male

Age of household head

Head has completed at least primary schooling

Head has no formal schooling

\# Adults in household

\# 6-15 year old children in household

\# children below age 6 in household

Household has resided in village for less than 4 years

Cultivable land owned (Hectares)

\# Sleeping Rooms in dwelling

Household has non-farm business more than 3 years old Intercept

$\begin{aligned} 0.0656 & (0.0221)^{* * *} \\ -0.0004 & (0.0006) \\ -0.0040 & (0.0278) \\ -0.0664 & (0.0202)^{* * *} \\ 0.0091 & (0.0071) \\ 0.0220 & (0.0055)^{* * *} \\ 0.0199 & (0.0083)^{* *} \\ -0.1384 & (0.0642)^{* *} \\ 0.0205 & (0.0042)^{* * *} \\ 0.0239 & (0.0145) \\ 0.0622 & (0.0245)^{* *} \\ 0.1119 & (0.0416)\end{aligned}$

Notes: Endline data (2006) from PAs where ACSI/OCSSC operated during the study period. Standard errors (in parenthesis) are robust to intra-PA correlation. The figures correspond to OLS estimates with sampling weights of a linear probability model where the dependent variable is a dummy $=1$ if the household has an outstanding micro-loan at follow-up. The regression also includes PA fixed effects. None of the predicted probabilities of borrowing lie outside the unit interval $(\min =0.034, \max =0.808$, mean $=0.268)$. Sample size $n=3,528$, with 23 observations $(<1 \%)$ dropped because of missing values in one or more of the predictors. Asterisks denote statistical significance at the $10(*), 5(* *)$ or $1(* * *) \%$ level. 


\section{A.8 Impacts on Self-employment Activities: Expenses and Revenues, Complete Results and Alternative Specifications}

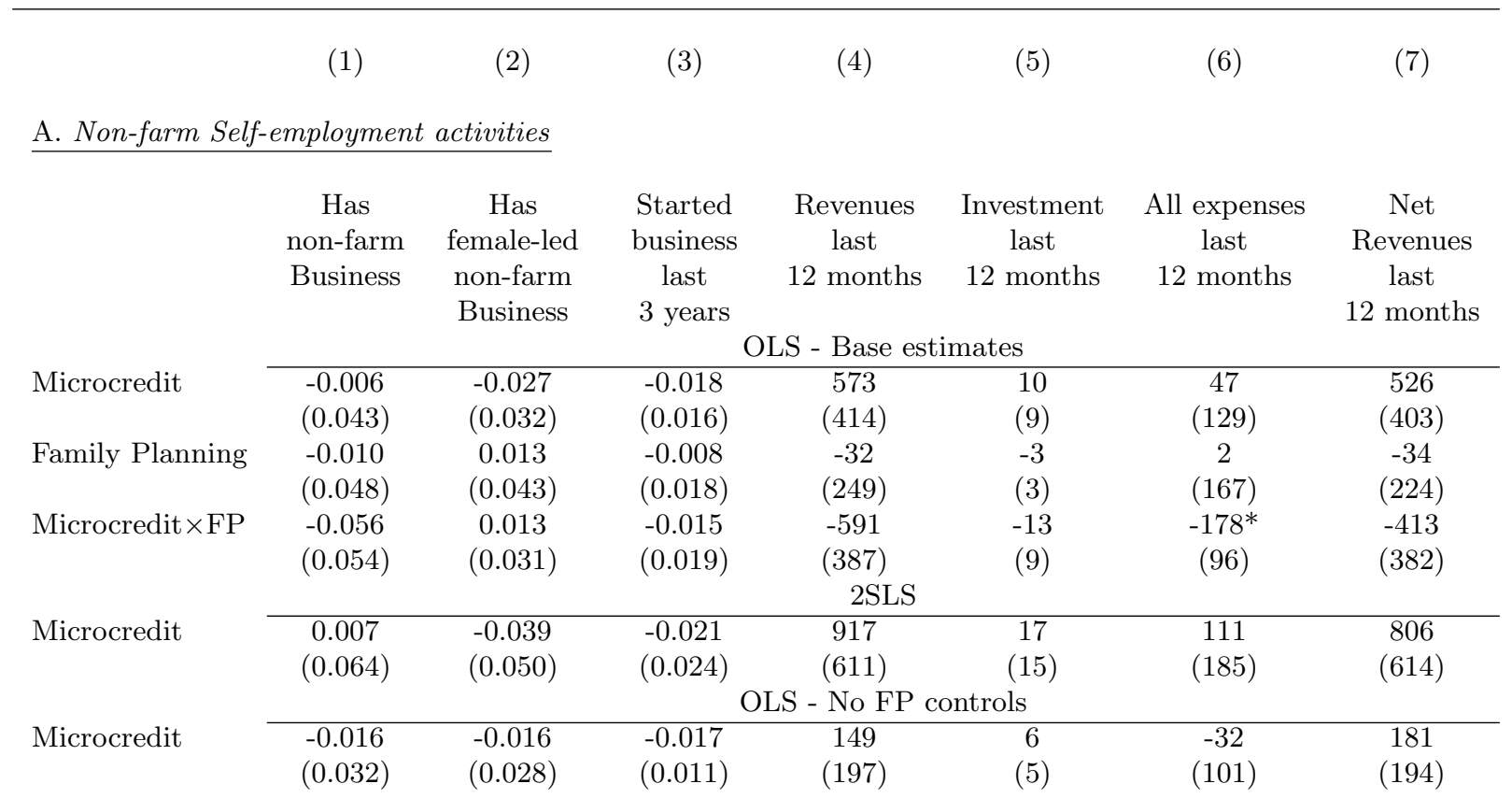

B. Crop Cultivation and Animal Husbandry

\begin{tabular}{|c|c|c|c|c|c|c|}
\hline $\begin{array}{l}\text { Cash } \\
\text { revenues } \\
\text { from } \\
\text { crops }\end{array}$ & $\begin{array}{l}\text { Expenses } \\
\text { for crop } \\
\text { cultivation } \\
\text { last } 12 \mathrm{~m}\end{array}$ & $\begin{array}{c}\text { Net } \\
\text { revenues } \\
\text { from crop } \\
\text { last } 12 \mathrm{~m}\end{array}$ & $\begin{array}{c}\text { Land } \\
\text { cultivated } \\
\text { last } 12 \mathrm{~m} \\
\text { (hectares) }\end{array}$ & $\begin{array}{c}\text { Value of } \\
\text { livestock } \\
\text { owned }\end{array}$ & $\begin{array}{c}\text { Value of } \\
\text { large } \\
\text { animals } \\
\text { owned }\end{array}$ & $\begin{array}{l}\text { Livestock } \\
\text { sales } \\
\text { last } 12 \mathrm{~m}\end{array}$ \\
\hline
\end{tabular}

\begin{tabular}{|c|c|c|c|c|c|c|c|}
\hline \multirow{3}{*}{ Microcredit } & \multicolumn{7}{|c|}{ OLS - Base estimates } \\
\hline & 63 & $154^{* *}$ & 1 & 0.08 & 206 & 198 & $77^{* *}$ \\
\hline & $(219)$ & $(75)$ & $(196)$ & $(0.13)$ & $(258)$ & $(243)$ & $(38)$ \\
\hline \multirow[t]{2}{*}{ Family Planning } & -198 & -56 & -216 & 0.01 & 315 & 337 & 105 \\
\hline & $(174)$ & $(60)$ & $(152)$ & $(0.14)$ & $(436)$ & $(407)$ & $(94)$ \\
\hline \multirow[t]{3}{*}{ Microcredit $\times$ FP } & $-290^{*}$ & $-150^{* *}$ & -240 & -0.17 & 235 & 252 & -10 \\
\hline & $(171)$ & $(75)$ & $(155)$ & $(0.13)$ & $(302)$ & $(309)$ & $(64)$ \\
\hline & & & & $2 \mathrm{SL}$ & & & \\
\hline \multirow[t]{3}{*}{ Microcredit } & 148 & $241^{* *}$ & 53 & 0.157 & 230 & 217 & $112^{*}$ \\
\hline & $(320)$ & $(107)$ & $(292)$ & $(0.217)$ & $(389)$ & $(365)$ & $(60)$ \\
\hline & \multicolumn{7}{|c|}{ OLS - No FP controls } \\
\hline \multirow[t]{2}{*}{ Microcredit } & 6 & $99^{*}$ & -31 & -0.017 & 39 & 46 & 24 \\
\hline & $(139)$ & $(50)$ & $(117)$ & $(0.129)$ & $(361)$ & $(340)$ & $(64)$ \\
\hline
\end{tabular}

Notes: Data from 2003 and 2006 surveys. Standard errors (in parenthesis) are robust to intra-PA correlation. All estimates are obtained from 2SLS. The base estimates are those labeled "PA Fixed Effects with FP-treatment controls", corresponding to model (1) in the text. For these results, the estimates in the row labeled 'Microcredit' are identical to those in Table 3 , while those in the rows below show the results for $\hat{\beta}_{F P}$ and $\hat{\beta}_{B o t h}$. The results labeled "2SLS" are obtained estimating model (1) replacing assigned treatment with actual treatment and using the former indicators as instruments for the latter. The estimates labeled "OLS - No FP controls" are obtained ignoring the presence of Family Planning Programs, that is, imposing $\beta_{F P}=\beta_{B o t h}=0$ in model (1), with PA fixed effects. Asterisks denote statistical significance at the $10\left(^{*}\right), 5(* *)$ or $1(* * *) \%$ level. 


\section{A.9 Impacts on Income Indicators, Complete Results and Alternative Specifi- cations}

\begin{tabular}{|c|c|c|c|c|c|c|}
\hline & (1) & (2) & (3) & (4) & (5) & (6) \\
\hline & \multicolumn{6}{|c|}{ Household income last 12 months } \\
\hline & $\begin{array}{c}\text { Total } \\
\text { revenues } \\
\text { from self } \\
\text { employment } \\
\text { activities }\end{array}$ & $\begin{array}{c}\text { Total } \\
\text { costs } \\
\text { from self } \\
\text { employment } \\
\text { activities }\end{array}$ & $\begin{array}{l}\text { Total net } \\
\text { revenues } \\
\text { from self } \\
\text { employment } \\
\text { activities }\end{array}$ & Wages & Transfers & $\begin{array}{l}\text { Other } \\
\text { Income }\end{array}$ \\
\hline Microcredit & $\begin{array}{c}712 \\
(479)\end{array}$ & $\begin{array}{c}199 \\
(156)\end{array}$ & $\begin{array}{c}513 \\
(431)\end{array}$ & $\begin{array}{l}48.7 \\
(84)\end{array}$ & $\begin{array}{c}-10.8 \\
(17)\end{array}$ & $\begin{array}{l}28.1 \\
(19)\end{array}$ \\
\hline Family Planning & $\begin{array}{l}-125 \\
(306)\end{array}$ & $\begin{array}{l}-116 \\
(157)\end{array}$ & $\begin{array}{l}-8.66 \\
(285)\end{array}$ & $\begin{array}{l}106 \\
(92)\end{array}$ & $\begin{array}{l}0.47 \\
(14)\end{array}$ & $\begin{array}{c}-55.9 \\
(39)\end{array}$ \\
\hline Microcredit $\times$ FP & $\begin{array}{c}-891^{* *} \\
(448)\end{array}$ & $\begin{array}{c}-336^{* *} \\
(136)\end{array}$ & $\begin{array}{l}-555 \\
(415) \\
2 S L S\end{array}$ & $\begin{array}{l}2.06 \\
(73)\end{array}$ & $\begin{array}{c}-29.2 \\
(34)\end{array}$ & $\begin{array}{c}-68.2^{* * *} \\
(21)\end{array}$ \\
\hline \multirow[t]{2}{*}{ Microcredit } & $\begin{array}{c}1177^{*} \\
(682)\end{array}$ & $\begin{array}{c}347 \\
(215)\end{array}$ & $\begin{array}{c}830 \\
(645)\end{array}$ & $\begin{array}{c}71.3 \\
(127)\end{array}$ & $\begin{array}{c}-6.31 \\
(30)\end{array}$ & $\begin{array}{c}51.9^{*} \\
(27)\end{array}$ \\
\hline & \multicolumn{6}{|c|}{ OLS - No FP controls } \\
\hline Microcredit & $\begin{array}{c}179 \\
(261)\end{array}$ & $\begin{array}{c}94.7 \\
(104)\end{array}$ & $\begin{array}{c}83.9 \\
(233)\end{array}$ & $\begin{array}{c}-12.3 \\
(51)\end{array}$ & $\begin{array}{c}-0.522 \\
(5)\end{array}$ & $\begin{array}{c}8.67 \\
(9)\end{array}$ \\
\hline
\end{tabular}

Notes: Data from 2003 and 2006 surveys. Standard errors (in parenthesis) are robust to intra-PA correlation. The base estimates are those labeled "PA Fixed Effects with FP-treatment controls", corresponding to model (1) in the text. For these results, the estimates in the row labeled 'Microcredit' are identical to those in Table 4, while those in the rows below show the results for $\hat{\beta}_{F P}$ and $\hat{\beta}_{B o t h}$. The results labeled "2SLS" are obtained estimating model (1) replacing assigned treatment with actual treatment and using the former indicators as instruments for the latter. The estimates labeled "OLS - No FP controls" are obtained ignoring the presence of Family Planning Programs, that is, imposing $\beta_{F P}=\beta_{\text {Both }}=0$ in model (1), with PA fixed effects. Revenues (column 1) is the sum of revenues from sales of crop or livestock and products from non-farm businesses. Costs (column 2) is the sum of all costs for crop cultivation or non-farm businesses plus costs for animals purchased. Net revenues (column 3) is the difference between the two. See Appendix A.1 for additional details. All figures expressing monetary values are in 2006 Birr. The PPP exchange rate according to the latest World Bank figures is 2.25 Birr/1USD (World Bank 2008). Asterisks denote statistical significance at the $10(*), 5(* *)$ or $1(* * *) \%$ level. 


\section{A.10 Impacts on Income Indicators, Complete Results and Alternative Speci- fications}

(1)

$(2)$
(3)

$(4)$
$(5)$

Panel A: Hours work / week: members 16-75 years old

\begin{tabular}{|c|c|c|c|}
\hline $\begin{array}{l}\text { All adults } \\
\text { All }\end{array}$ & $\begin{array}{l}\text { All adults } \\
\text { Self }\end{array}$ & $\begin{array}{l}\text { All adults } \\
\text { Outside }\end{array}$ & $\begin{array}{l}\text { Women } \\
\text { Self }\end{array}$ \\
\hline
\end{tabular}

\begin{tabular}{lccccc} 
& \multicolumn{5}{c}{ OLS - Base estimates } \\
\cline { 2 - 6 } Microcredit & 1.09 & 0.949 & 0.139 & -1.11 & 0.979 \\
& $(1.43)$ & $(1.17)$ & $(0.68)$ & $(1.04)$ & $(1.03)$ \\
Family Planning & -0.728 & -1.59 & 0.862 & -1.38 & $2.12^{* *}$ \\
& $(1.31)$ & $(1.52)$ & $(0.78)$ & $(1.16)$ & $(1.05)$ \\
Microcredit×FP & -2.09 & $-2.11^{*}$ & 0.0205 & -0.0481 & 0.16 \\
& $(1.29)$ & $(1.19)$ & $(0.66)$ & $(0.81)$ & $(0.89)$ \\
Microcredit & \multicolumn{5}{c}{ 2SLS } \\
\cline { 2 - 6 } & $(2.17)$ & $(1.88)$ & 0.231 & -1.52 & 1.36 \\
Microcredit & -0.315 & -0.156 & -0.159 & $(1.54)$ & $(1.53)$ \\
& $(0.62)$ & $(0.62)$ & $(0.42)$ & -0.326 & -0.0595 \\
& & \multicolumn{5}{c}{$(0.56)$} & $(0.59)$
\end{tabular}

Panel B: Hours work / week: teens 13-19 years old

$\begin{array}{ccccc}\text { All teens } & \text { All teens } & \text { All teens } & \text { Girls } & \text { Girls } \\ \text { All } & \text { Self } & \text { Outside } & \text { Self } & \text { Outside } \\ \text { Activities } & \text { employment } & \text { employment } & \text { employment } & \text { employment }\end{array}$

\begin{tabular}{lccccc} 
& \multicolumn{5}{c}{ OLS - Base estimates } \\
\cline { 2 - 6 } Microcredit & -0.72 & -1.72 & $1^{*}$ & $-2.64^{*}$ & 0.531 \\
& $(1.42)$ & $(1.53)$ & $(0.54)$ & $(1.52)$ & $(0.66)$ \\
Family Planning & -2.03 & -3.38 & $1.35^{* *}$ & -1.89 & -0.329 \\
& $(2.57)$ & $(2.82)$ & $(0.63)$ & $(1.77)$ & $(0.72)$ \\
Microcredit×FP & -1.34 & 0.2 & $-1.54^{* * *}$ & 0.747 & -0.599 \\
& $(1.60)$ & $(1.64)$ & $(0.58)$ & $(1.35)$ & $(0.57)$ \\
Microcredit & -0.647 & -2.38 & $1.74^{*}$ & $-3.54^{*}$ & 0.787 \\
& $(1.98)$ & $(2.18)$ & $(0.90)$ & $(2.13)$ & $(0.90)$ \\
Microcredit & -1.56 & -1.36 & -0.204 & $-1.42^{*}$ & 0.0412 \\
& $(1.01)$ & $(0.94)$ & $(0.32)$ & $(0.75)$ & $0.38)$
\end{tabular}

Notes: Data from 2003 and 2006 surveys. Standard errors (in parenthesis) are robust to intra-PA correlation. The base estimates are those labeled "PA Fixed Effects with FP-treatment controls", corresponding to model (1) in the text. For these results, the estimates in the row labeled 'Microcredit' are identical to those in Table 5, while those in the rows below show the results for $\hat{\beta}_{F P}$ and $\hat{\beta}_{B o t h}$. The results labeled "2SLS" are obtained estimating model (1) replacing assigned treatment with actual treatment and using the former indicators as instruments for the latter. The estimates labeled "OLS - No FP controls" are obtained ignoring the presence of Family Planning Programs, that is, imposing $\beta_{F P}=\beta_{B o t h}=0$ in model (1), with PA fixed effects. Hours of work are estimated from recall data about time allocation in the previous 12 months, see Appendix A.1 for details. Asterisks denote statistical significance at the $10(*), 5(* *)$ or $1(* * *) \%$ level. 


\section{A.11 Impacts on Child Schooling and Other Socio-economic Indicators, Com- plete Results and Alternative Specifications}

(1)

$(2)$
(3)
(4)

Panel A: School attendance and time allocation of children

\begin{tabular}{|c|c|c|c|c|c|}
\hline & \multirow{2}{*}{$\begin{array}{c}\% \text { of } \\
\text { children } \\
6-15 \text { in } \\
\text { school }\end{array}$} & \multicolumn{2}{|c|}{$\begin{array}{l}\text { Average hours/week worked } \\
\text { by children } 10-15\end{array}$} & \multirow{2}{*}{$\begin{array}{l}\% \text { of } 10-15 \\
\text { girls for whom } \\
\text { housework is } \\
\text { primary activity }\end{array}$} & \multirow{2}{*}{$\begin{array}{c}\% \text { of } \\
16-20 \\
\text { in } \\
\text { school }\end{array}$} \\
\hline & & $\begin{array}{c}\text { Self } \\
\text { employment }\end{array}$ & $\begin{array}{c}\text { Outside } \\
\text { activities } \\
\text { OLS - Base est }\end{array}$ & & \\
\hline Microcredit & $\begin{array}{l}0.02 \\
(0.05)\end{array}$ & $\begin{array}{l}-0.61 \\
(1.71)\end{array}$ & $\begin{array}{l}-0.01 \\
(0.59)\end{array}$ & $\begin{array}{c}0.05 \\
(0.04)\end{array}$ & $\begin{array}{c}0.01 \\
(0.03)\end{array}$ \\
\hline Family Planning & $\begin{array}{l}0.06 \\
(0.05)\end{array}$ & $\begin{array}{l}-3.97 \\
(2.93)\end{array}$ & $\begin{array}{c}0.61 \\
(0.72)\end{array}$ & $\begin{array}{l}-0.01 \\
(0.03)\end{array}$ & $\begin{array}{c}0.05 \\
(0.03)\end{array}$ \\
\hline Microcredit $\times$ FP & $\begin{array}{c}0.04 \\
(0.04)\end{array}$ & $\begin{array}{l}-2.68 \\
(2.10)\end{array}$ & $\begin{array}{l}-0.49 \\
(0.49) \\
\text { 2SLS }\end{array}$ & $\begin{array}{l}-0.06 \\
(0.04)\end{array}$ & $\begin{array}{c}0.06 \\
(0.04)\end{array}$ \\
\hline Microcredit & $\begin{array}{c}0.023 \\
(0.064)\end{array}$ & $\begin{array}{l}-0.186 \\
(2.470)\end{array}$ & $\begin{array}{l}0.163 \\
(0.90)\end{array}$ & $\begin{array}{c}0.07 \\
(0.054)\end{array}$ & $\begin{array}{l}-0.0005 \\
(0.0433)\end{array}$ \\
\hline Microcredit & $\begin{array}{c}0.025 \\
(0.029)\end{array}$ & $\begin{array}{l}-2.050^{*} \\
(1.120)\end{array}$ & $\begin{array}{c}-0.634^{* *} \\
(0.314)\end{array}$ & $\begin{array}{c}\text { Dls } \\
0.006 \\
(0.028)\end{array}$ & $\begin{array}{c}0.007 \\
(0.037)\end{array}$ \\
\hline
\end{tabular}

Panel B: Other indicators

\begin{tabular}{|c|c|c|c|c|c|}
\hline & \multicolumn{2}{|c|}{$\begin{array}{c}\text { Empowerment: } \\
\% \text { decisions with } \\
\text { woman's involvement }\end{array}$} & \multirow{2}{*}{$\begin{array}{c}\text { Value of } \\
\text { selected } \\
\text { assets }\end{array}$} & \multirow[t]{2}{*}{$\begin{array}{l}\text { Someone } \\
\text { seriously ill } \\
\text { last } 3 \text { years }\end{array}$} & \multirow[t]{2}{*}{$\begin{array}{l}\text { \# Months } \\
\text { of food } \\
\text { insecurity }\end{array}$} \\
\hline & All & Economic & & & \\
\hline Microcredit & $\begin{array}{c}-0.0465 \\
(0.04)\end{array}$ & $\begin{array}{c}-0.0415 \\
(0.04)\end{array}$ & $\begin{array}{c}-5 \\
(13)\end{array}$ & $\begin{array}{c}-0.015 \\
(0.034)\end{array}$ & $\begin{array}{c}0.524 \\
(0.26)\end{array}$ \\
\hline Family Planning & $\begin{array}{l}(0.08) \\
(0.05)\end{array}$ & $\begin{array}{l}(0.10) \\
(0.06)\end{array}$ & $\begin{array}{l}23^{*} \\
(12)\end{array}$ & $\begin{array}{c}0.028 \\
(0.031)\end{array}$ & $\begin{array}{c}0.102 \\
(0.23)\end{array}$ \\
\hline Microcredit $\times$ FP & $\begin{array}{c}0.0133 \\
(0.04)\end{array}$ & $\begin{array}{c}0.0256 \\
(0.05)\end{array}$ & $\begin{array}{l}-19 \\
(14) \\
2 \mathrm{SL}\end{array}$ & $\begin{array}{c}0.004 \\
(0.034)\end{array}$ & $\begin{array}{c}-0.126 \\
(0.30)\end{array}$ \\
\hline Microcredit & $\begin{array}{c}-0.071 \\
(0.060)\end{array}$ & $\begin{array}{l}-0.070 \\
(0.065)\end{array}$ & $\begin{array}{c}-3 \\
(19) \\
\text { S - No FF }\end{array}$ & $\begin{array}{l}-0.018 \\
(0.052)\end{array}$ & $\begin{array}{c}0.74 \\
(0.422)\end{array}$ \\
\hline Microcredit & $\begin{array}{c}-0.002 \\
(0.023)\end{array}$ & $\begin{array}{c}0.007 \\
(0.027)\end{array}$ & $\begin{array}{c}2 \\
(9)\end{array}$ & $\begin{array}{c}-0.029 \\
(0.024)\end{array}$ & $\begin{array}{c}0.20 \\
(0.165)\end{array}$ \\
\hline
\end{tabular}

Notes: Data from 2003 and 2006 surveys. Standard errors (in parenthesis) are robust to intra-PA correlation. The base estimates are those labeled "PA Fixed Effects with FP-treatment controls", corresponding to model (1) in the text. For these results, the estimates in the row labeled 'Microcredit' are identical to those in Table 5, while those in the rows below show the results for $\hat{\beta}_{F P}$ and $\hat{\beta}_{B o t h}$. The results labeled "2SLS" are obtained estimating model (1) replacing assigned treatment with actual treatment and using the former indicators as instruments for the latter. The estimates labeled "OLS - No FP controls" are obtained ignoring the presence of Family Planning Programs, that is, imposing $\beta_{F P}=\beta_{B o t h}=0$ in model (1), with PA fixed effects. The results in column 4, Panel B, use only information from the endline survey because no information was collected at baseline (in this case we exclude the PA-specific fixed effects and the Post dummy and we include a region fixed effect). All regressions use sampling weights. The unit of observation is a child in all regressions of panel A, a woman in columns 1 and 2 of Panel B, and a household in columns 3 to 5 of Panel B. Asterisks denote statistical significance at the $10\left({ }^{*}\right), 5(* *)$ or $1\left(^{* * *}\right) \%$ level. 